\title{
Retinoic acid signalling during development
}

\author{
Muriel Rhinn* and Pascal Dollé*
}

\begin{abstract}
Summary
Retinoic acid (RA) is a vitamin A-derived, non-peptidic, small lipophilic molecule that acts as ligand for nuclear RA receptors (RARs), converting them from transcriptional repressors to activators. The distribution and levels of RA in embryonic tissues are tightly controlled by regulated synthesis through the action of specific retinol and retinaldehyde dehydrogenases and by degradation via specific cytochrome P450s (CYP26s). Recent studies indicate that RA action involves an interplay between diffusion (morphogen-like) gradients and the establishment of signalling boundaries due to RA metabolism, thereby allowing RA to finely control the differentiation and patterning of various stem/progenitor cell populations. Here, we provide an overview of the RA biosynthesis, degradation and signalling pathways and review the main functions of this molecule during embryogenesis.
\end{abstract}

Key words: Retinoids, Retinoic acid, Retinol dehydrogenase (RDH), Retinaldehyde dehydrogenase (RALDH), CYP26, Hindbrain, Forebrain

\section{Introduction}

Retinoic acid (RA) is derived from the liposoluble vitamin A (retinol). Vitamin A has long been known to be indispensable for vision, as its derivative retinaldehyde (Fig. 1) acts as a lightsensitive molecule, the isomerisation of which triggers the phototransduction process in photoreceptor cells of the retina (reviewed by Parker and Crouch, 2010). Many other functions have been assigned to this vitamin, and work in avian and rodent models has established that maternal vitamin A deficiency affects the embryo and foetus, leading to a complex spectrum of abnormalities (e.g. Gale et al., 1999; White et al., 2000; Wilson et al., 1953). About 25 years ago, the molecular basis of vitamin A action was elucidated when it was shown that its acidic metabolite, RA, acts as a ligand for transcription factors of the retinoic acid receptor (RAR) nuclear receptor superfamily, switching them from potential repressors to transcriptional activators.

Possible functions of RA during embryogenesis were first inferred by studying its teratogenic effects, i.e. how the administration of excess doses of RA, either globally or by local implantation using RA-impregnated beads, interferes with normal developmental processes. These studies have been performed in a wide range of species including amphibians, zebrafish, chick and rodents (e.g. Avantaggiato et al., 1996; Durston et al., 1989). Gene knockout studies then confirmed the crucial functions of RARs in mouse development (reviewed by Mark et al., 2009). Eventually, the enzymatic pathways that regulate embryonic RA synthesis from maternal retinol - or egg-stored retinoids - were characterised, and

IGBMC (Institut de Génétique et de Biologie Moléculaire et Cellulaire), BP 10142 , Illkirch, F-67404 France, and Inserm, U 964, CNRS, UMR 7104, Université de Strasbourg, France.

*Authors for correspondence (rhinn@igbmc.fr; dolle@igbmc.fr) it was found that another regulatory step involved the triggering of RA catabolism by a subfamily of cytochrome P450 enzymes. Altogether, the differential and often dynamic expression patterns of a small number of specific synthesizing and metabolising enzymes allow precise control of RA distribution within embryonic cell populations. A wide range of vertebrate models (from zebrafish to mouse) and experimental tools (including, for instance, reporter transgenes that reveal regions of active RA signalling, and selective antagonists for RARs or RA-synthesizing/metabolising enzymes) have been successfully used to decipher retinoid functions at the cellular and molecular levels.

Here, we first provide an overview of the pathways and proteins that regulate or mediate RA signalling during development, many of which appear to be highly conserved throughout vertebrate species. We then review the main functions of retinoid signalling during early embryonic development, first referring to the developing hindbrain as a system that has been most extensively studied with respect to RA functions and for which recent studies have refined our knowledge of the control of RA activity during rhombomeric segmentation. We further review extensive work that, over the last few years, has investigated how RA acts on progenitor cell populations in structures as diverse as the embryonic forebrain, the branchial apparatus and foregut derivatives, the neural plate and the posterior mesoderm during embryonic axial elongation. Understanding these functions and the underlying molecular events is of great importance, as retinoids are widely used in therapy and in many protocols for differentiating primary cultures or cell lines [including embryonic stem (ES) cells] into specific lineages (see Box 1). Retinoids thus hold promise for future use in stem cellbased therapy and regenerative medicine. Ongoing research will also guide more conventional clinical approaches, especially in the context of cancer chemoprevention or treatment (reviewed by Tang and Gudas, 2011).

\section{The RA synthesis pathway}

The only source of retinoids in most animals is diet derived, as these compounds cannot be synthesized de novo. In mammals, the main circulating retinoid is retinol bound to a carrier protein, retinol-binding protein 4 (RBP4) (see Box 2). Retinol homeostasis involves several proteins and enzymes that regulate its dietary uptake in intestinal cells and its storage mainly in liver hepatocytes and stellate cells (reviewed by D'Ambrosio et al., 2011). Maternal retinol transferred transplacentally is the major retinoid source for embryos of placental species. By contrast, oviparous species store vitamin A in the egg yolk and, according to the species, the main source can be retinol, retinaldehyde, or carotenoids such as betacarotene (see Simoes-Costa et al., 2008). Work performed in zebrafish has demonstrated the importance of a beta-carotene cleavage enzyme (BCMO1) that acts tissue-specifically to generate embryonic retinaldehyde (Lampert et al., 2003).

Typically, in mammals, retinol-RBP4 is taken up by target tissues, and this uptake can be facilitated in some tissues by a transmembrane protein that is the product of the RA-inducible gene 
A
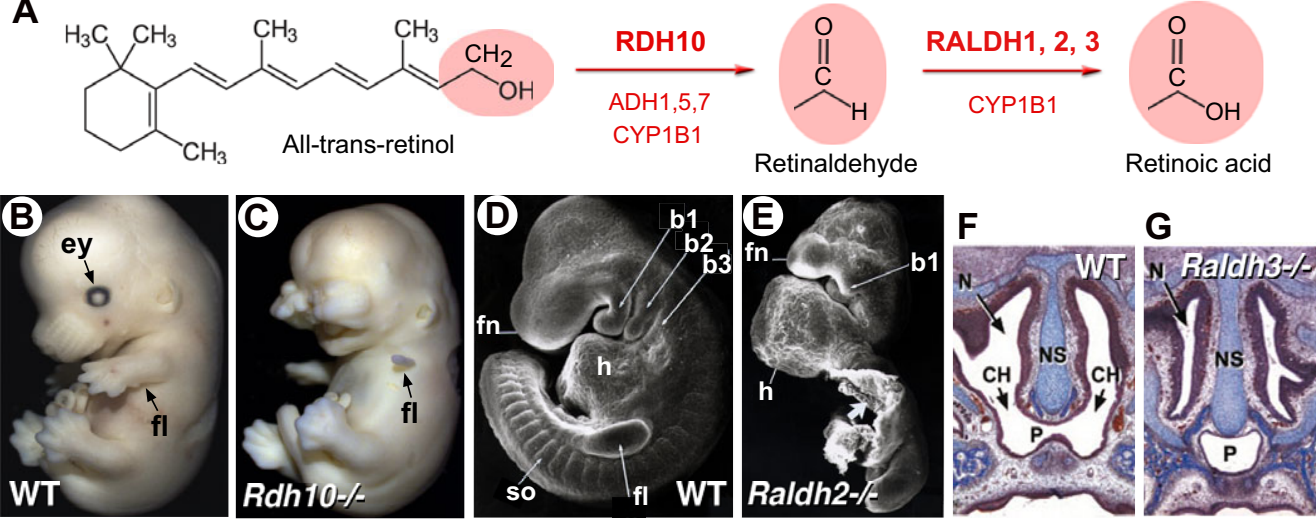

Fig. 1. Retinoic acid biosynthesis. (A) The oxidation of retinol into retinaldehyde and retinoic acid (RA). Enzymes responsible for each of the catalytic steps are shown, with enzymes that are crucial for normal development in bold. (B-G) The phenotypes of murine mutants lacking RDH10,

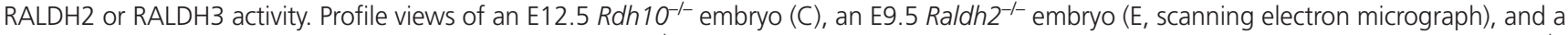

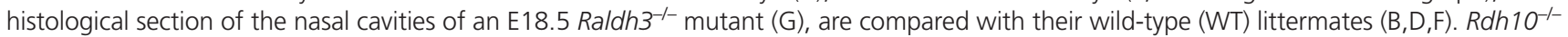
mutants exhibit abnormal facial development, lack of externally visible eyes (ey) and severe forelimb (fl) defects. Raldh $2^{-/-}$mutants show an array of abnormalities, with hypoplasia of the frontonasal region ( $\mathrm{fn}$ ) and telencephalic vesicles, lack of posterior branchial arches (b1-b3), defective heart ( $h$ ) morphogenesis, shortened trunk region (bold arrow) with compacted somites (so), and absent forelimb buds. Raldh $3^{-1-}$ mutants fail to develop choanae ( $\mathrm{CH}$; the ducts connecting the nasal and oral cavities), leading to lethal respiratory distress at birth. N, nasal cavity; NS, nasal septum; P, pharynx. Reproduced with permission: B,C (Rhinn et al., 2011); D,E (Niederreither et al., 1999); F,G (Dupé et al., 2003).

STRA6 (Kawaguchi et al., 2007). Interestingly, STRA6 mutations constitute the only demonstrated cases of human mutations that affect a gene from the retinoid pathway and lead to a complex spectrum of developmental abnormalities (Pasutto et al., 2007). Other human mutations involving retinoid-binding proteins selectively affect visual function (e.g. Maw et al., 1997). Maternal RBP4 cannot cross the placenta; retinol thus diffuses across the yolk sac and placenta, where zygotic RBP4 synthesis occurs (Ward et al., 1997). Retinyl esters may also be significant retinoid sources for the embryo (Quadro et al., 2005).

\section{Box 1. RA and stem cell differentiation}

Unlike many other adult tissues, the nervous system of mammals has a limited ability to compensate for the loss of cells after lesions. Embryonic stem (ES) cells have long attracted attention as a potential source of cells that can be driven to differentiate into specific lineages for the development of cell therapy and pharmaceutical screens. The spontaneous development of neuronal cells from ES cells during in vitro culture is rather limited. Therefore, various protocols to increase the differentiation of neuronal cell types have been established. Recently, it was found that the addition of RA to rapidly proliferating mouse ES cells, cultured in suspension as embryoid bodies, leads to the selective generation of neural progenitors with characteristics of radial glial cells found in the developing central nervous system (Bibel et al., 2004; Plachta et al., 2004). These conditions led to a highly uniform population of Pax6-positive cells which, when further cultured in vitro, could differentiate into neurons that established synaptic contacts and exhibited electrophysiological properties similar to those of forebrain pyramidal neurons. When transplanted into the neural tube of chicken embryos, the RA-induced embryoid bodies contributed to spinal cord motoneurons and interneurons. In the future, these cellular systems could be used for studying commitment and neuronal specification in vitro, for pharmacological assays and drug screening, and for the selective isolation of differentiated neuronal cells or committed progenitors that may be used as a source for cell and tissue grafts.
Enzymes that oxidize retinol to retinaldehyde (Fig. 1A) belong to two classes: the cytosolic alcohol dehydrogenases (ADHs) belonging to the medium-chain dehydrogenase/reductase family; and microsomal short-chain dehydrogenases/reductases (retinol dehydrogenases, RDHs) (reviewed by Pares et al., 2008). ADH5 (previously called ADH3) is ubiquitously expressed in the embryo and adult, whereas ADH1 and ADH7 (previously called ADH4) are tissue restricted (Ang et al., 1996). Null mouse mutants for Adh5 display reduced viability and growth defects, which can be rescued by dietary supplementation with retinol (Molotkov et al., 2002a). No obvious phenotype is associated with the loss of ADH1 and ADH7 when mice are maintained on a vitamin A-sufficient diet (Deltour et al., 1999b). However, when large doses of retinol are administered to $A d h 1^{--}$mutants, the mice are more sensitive to vitamin A embryotoxicity (Molotkov et al., 2002b). This suggests that ADH enzymes might have a role in controlling the removal of excess retinol, rather than participating in RA synthesis. RDHs are well known to act during the visual cycle (Parker and Crouch, 2010). $R d h 5^{-/-}$mice are viable but suffer from a delay in dark adaptation, consistent with a role in regenerating 11-cisretinaldehyde after photobleaching. By contrast, Rdh10, which displays specific expression domains during development (Cammas et al., 2007; Romand et al., 2008) (Table 1), plays an important role in RA synthesis, as its loss-of-function is lethal between embryonic day (E) 10.5 and E14.5 (Sandell et al., 2007). Rdh10 mutants (Fig. 1B,C) exhibit abnormalities characteristic of RA deficiency (Table 2), which can be partly rescued by maternal RA supplementation (Rhinn et al., 2011).

The next step in RA synthesis is the oxidation of retinaldehyde to RA (Fig. 1A), which is carried out by three retinaldehyde dehydrogenases (RALDHs): RALDH1, RALDH2 and RALDH3 (also known as ALDH1A1, ALDH1A2 and ALDH1A3). RALDHs display distinct and specific expression patterns that correlate with RA activity as detected by reporter transgenes (Table 1). Raldh2 is the earliest RALDH to be expressed, and is found in the primitive streak and mesodermal cells, and later in somitic and lateral mesoderm, posterior heart tube and rostral forebrain (Niederreither 


\section{Box 2. Additional components of the retinoid pathway}

Retinol-binding protein 4 (RBP4). Mainly synthesized in the yolk sac and postnatally in liver. It binds to retinol and delivers retino from the liver to peripheral tissues.

Transthyretin (TTR). A serum protein that associates with RBP4retinol to prevent retinol degradation by the kidney. The TTR-RBP4retinol complex transports retinol in the circulation and delivers it to target tissues.

'Ocular' retinoid-binding proteins. These include retinaldehydebinding proteins 1 and 3 (RLBP1 and RBP3), which are produced by retinal cells and are involved in the isomerisation and/or shuttling of retinol and retinaldehyde during the visual cycle.

Cytochrome P450 1B1 (CYP1B1). May catalyze the oxidation of retinol into retinaldehyde and RA. Human CYP1B1 mutations are a major cause of congenital glaucoma, a severely blinding disease.

Cellular retinol-binding proteins (CRBP-I and -II, also known as RBP1 and 2). These proteins belong to the fatty acid-binding protein (FABP) family. They bind both all-trans-retinol and all-transretinaldehyde, and may function to control levels of intracellular retinol accumulation and esterification.

Cellular retinoic acid-binding proteins (CRABP-I and -II, also known as CRABP1 and 2). Bind all-trans-RA intracellularly. They solubilise and protect RA in the aqueous cytosol, although differential functions have been proposed, with CRABP-I presenting RA to metabolising (CYP26) enzymes, and CRABP-Il favouring nuclear import and delivery of RA to RARs by direct protein-protein interactions.

Fatty acid-binding protein 5 (FABP5). Binds RA with a lower affinity than CRABPs, and may play a role in inducing a noncanonical RA signalling pathway. In cell lines, FABP5 favours RA binding to peroxisome proliferator-activated receptor $\beta / \gamma(\operatorname{PPAR} \beta / \gamma)$, which in turn can induce anti-apoptotic and proliferative responses when the FABP5 concentration exceeds that of CRABP-II.

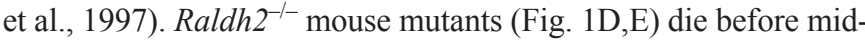
gestation from defective heart morphogenesis and exhibit numerous abnormalities (Table 2) (Niederreither et al., 1999; Niederreither et al., 2001; Niederreither et al., 2000). Some of these abnormalities can be rescued by transient maternal RA supplementation from E7.5 to E8.5-9.5 (e.g. Mic et al., 2002; Niederreither et al., 2003). RALDH2 is solely responsible for embryonic RA synthesis until $\sim$ E8.5, and thereafter RALDH1 and RALDH3 contribute to RA synthesis in the eyes and olfactory system. Raldh $3^{--}$mice have defects in nasal and ocular development and die at birth due to respiratory distress (Fig. 1F,G) (Dupé et al., 2003). Raldh $1^{--}$mutants, by contrast, are viable and show minor defects in the dorsal retina (Matt et al., 2005; Molotkov et al., 2006).

\section{The RA degradation pathway}

The distribution and levels of RA have to be tightly controlled during embryogenesis, and an important level of control is achieved through tissue-specific oxidative metabolism. Enzymes of the cytochrome P450 26 subfamily (CYP26A1, CYP26B1 and CYP26C1) catalyze reactions that convert RA into more polar metabolites, primarily 4-hydroxy-RA, which can be further oxidized to 4-oxo-RA (e.g. Chithalen et al., 2002) (Fig. 2A). Although 4-oxo-RA is able to bind RARs and interferes with embryonic patterning when administered exogenously (Pijnappel et al., 1993), both expression data and functional studies indicate that the role of CYP26-mediated RA metabolism is essentially to prevent inappropriate signalling in specific cell populations (reviewed by Pennimpede et al., 2010). CYP26 enzymes display differential expression patterns (Table 1) that are often complementary to the RALDH expression domains. Cyp26al and Cyp26c1 are the first to be expressed and are found in the rostralmost embryonic epiblast, and all three Cyp26 genes are expressed in a sequential manner during hindbrain development (MacLean et al., 2001; Sirbu et al., 2005) (see below). Cyp26al is specifically expressed in tail bud tissues and Cyp26b1 in distal limb bud mesenchyme (Yashiro et al., 2004). After mid-gestation, each Cyp26 gene displays complex patterns of expression in several developing organs, including the retina, inner ear and dental epithelium (Abu-Abed et al., 2002; Romand et al., 2006; Tahayato et al., 2003).

Genetic ablation of Cyp26a1 and Cyp26b1 results in phenotypes reminiscent of RA-induced teratogenesis (Table 2). Cyp26a1 $1^{-1-}$ mice (Fig. 2B,C) display truncation of the posterior body region, abnormal hindbrain patterning and transformation of cervical vertebrae (Abu-Abed et al., 2001; Sakai et al., 2001). Cyp26b1 $1^{-1-}$ mutants (Fig. 2D-G) exhibit severe limb malformations and facial abnormalities (MacLean et al., 2009; Yashiro et al., 2004). Cyp26c1 loss-of-function embryos are viable, although compound inactivation of any other Cyp26 results in early embryonic patterning defects (Uehara et al., 2007; Uehara et al., 2009) (Fig. 2H,I). Disruption of the P450 oxidoreductase (POR), an enzyme required for $\mathrm{P} 450$ cytochrome activity, phenocopies many of these defects, underscoring the importance of CYP26 function during development (Ribes et al., 2007).

Collectively, these data show that CYP26 enzymes have major developmental functions, which are best described as preventing any detrimental (teratogenic) effect of endogenous RA in regions where it should not be allowed to signal. Interestingly, RA can control the expression of its own metabolising enzymes. RA treatments in vivo and in cultured cells lead to rapid upregulation of the Cyp26a1 gene, which contains two functional RA-response elements (RAREs) (Loudig et al., 2005). These data have been integrated into mathematical models indicating how RA might participate in autoregulatory negative-feedback loops by inducing expression of catabolising enzyme(s) (White et al., 2007) (see below).

\section{Gene regulation by RA}

RA acts by binding to RARs, which are members of the nuclear receptor superfamily (reviewed by Rochette-Egly and Germain, 2009). There are three RARs (RAR $\alpha, \operatorname{RAR} \beta$ and RAR $\gamma$ ) that are conserved throughout vertebrates and that primarily bind all-transRA. RARs act in heterodimeric combinations with retinoid $X$ receptors (RXR $\alpha, \operatorname{RXR} \beta$ and $\mathrm{RXR} \gamma)$. RXRs bind a stereoisomer, 9-cis-RA, which, unlike all-trans-RA, is not detected endogenously in embryos or adult tissues (Mic et al., 2003); therefore, it was suggested that RXRs act mainly as scaffolding proteins to facilitate DNA binding of the RAR-RXR complex (see Chawla et al., 2001). Three receptors (RAR $\alpha, \operatorname{RXR} \alpha$ and $\mathrm{RXR} \beta$ ) have widespread expression patterns, whereas the others (RAR $\beta, \operatorname{RAR} \gamma$ and $R X R \gamma)$ show more complex, tissue-specific expression (reviewed by Dollé, 2009) (Table 1). Thus, most tissues are potential targets of retinoid actions, although different heterodimeric complexes can transduce the RA signal. Gene knockout studies in mouse revealed a large degree of functional redundancy between RAR/RXR heterodimers, with developmental abnormalities usually occurring when two receptors are inactivated in combination, except in the case of RXR $\alpha$ mutants, which die in utero due to heart defects (reviewed by Mark et al., 2009) (Table 2). 
Table 1. Expression patterns of RA pathway genes

\begin{tabular}{|c|c|c|}
\hline Gene & Main expression sites* & Main references $^{\ddagger}$ \\
\hline$R d h 10$ & $\begin{array}{l}\text { Ventral neural plate (hindbrain, spinal cord); mid-hindbrain isthmus; optic } \\
\text { vesicle, otocyst (ventral); nasal epithelium; dorsal somitic mesoderm, } \\
\text { mesonephros, lateral plate mesoderm; foregut mesenchyme and endoderm, } \\
\text { branchial pouches; proximal limb bud mesoderm }\end{array}$ & $\begin{array}{l}\text { Reijntjes et al., } 2010 \text { (chick); Cammas et } \\
\text { al., 2007; Sandell et al., } 2007 \text { (mouse) }\end{array}$ \\
\hline Raldh1 & $\begin{array}{l}\text { Ventral midbrain; optic vesicle, dorsal retina and lens; thymus primordium } \\
\text { (3rd branchial pouch) (mouse); posterior foregut and midgut endoderm } \\
\text { (chick); mesonephros }\end{array}$ & $\begin{array}{l}\text { Blentic et al., 2003; Suzuki et al., } 2000 \\
\text { (chick); Haselbeck et al., 1999; Li et al., } \\
\text { 2000; Suzuki et al., } 2000 \text { (mouse) }\end{array}$ \\
\hline Raldh2 & $\begin{array}{l}\text { Primitive streak, node, posterior embryonic mesoderm; anteriormost neural } \\
\text { plate and optic vesicle (transient); presomitic and somitic mesoderm, } \\
\text { mesonephros, lateral plate mesoderm; posterior branchial arches and } \\
\text { foregut mesenchyme; posterior heart tube }\end{array}$ & $\begin{array}{l}\text { Blentic et al., 2003; Haselbeck et al., } \\
\text { 1999; Swindell et al., } 1999 \text { (chick); } \\
\text { Niederreither et al., } 1997 \text {; Ribes et al., } \\
\text { 2009; Ribes et al., } 2006 \text { (mouse) }\end{array}$ \\
\hline Raldh3 & $\begin{array}{l}\text { Node (chick); head ectoderm, nasal epithelium, optic vesicle, dorsal and } \\
\text { ventral retina; otocyst (dorsal); mid-hindbrain isthmus; Rathke's pouch } \\
\text { (pituitary anlage) }\end{array}$ & $\begin{array}{l}\text { Blentic et al., 2003; Grun et al., 2000; } \\
\text { Suzuki et al., } 2000 \text { (chick); Li et al., } \\
2000 ; \text { Mic et al., 2000; Suzuki et al., } \\
2000 \text { (mouse) }\end{array}$ \\
\hline Сур26а1 & $\begin{array}{l}\text { Anteriormost epiblast and neural plate (transient); primitive streak and } \\
\text { posterior mesoderm; (pre)rhombomeres } 2 \text { (mouse), } 3 \text { and rostral spinal cord } \\
\text { (chick); posterior hindbrain and branchial arch mesenchyme; heart } \\
\text { endocardium; caudal neural plate and tail bud; distal limb bud ectoderm }\end{array}$ & $\begin{array}{l}\text { Blentic et al., 2003; Swindell et al., } 1999 \\
\text { (chick); Fujii et al., 1997; MacLean et al., } \\
\text { 2001; Sirbu et al., } 2005 \text { (mouse) }\end{array}$ \\
\hline Сyp26b1 & $\begin{array}{l}\text { (Pre)rhombomeres 3, 5, 2-4 (ventral) (mouse), 1, 4, } 6 \text { (chick); posterior (2nd- } \\
6 \text { th) branchial arch ectoderm/endoderm; distal limb bud mesenchyme; mid- } \\
\text { hindbrain isthmus; heart and vascular endothelia; tail bud (transient) }\end{array}$ & $\begin{array}{l}\text { Reijntjes et al., } 2003 \text { (chick); MacLean et } \\
\text { al., 2001; Sirbu et al., } 2005 \text { (mouse) }\end{array}$ \\
\hline Сур26с1 & $\begin{array}{l}\text { Rostral head mesenchyme (transient); (pre)rhombomeres 2, } 4 \text { (mouse), 2, 3, } 5 \\
\text { (chick); hindbrain mesenchyme (facing r3, and post-otic); first branchial arch } \\
\text { and pouch; otocyst (ventral) }\end{array}$ & $\begin{array}{l}\text { Reijntjes et al., } 2004 \text { (chick); Sirbu et al., } \\
\text { 2005; Tahayato et al., } 2003 \text { (mouse) }\end{array}$ \\
\hline Rara & $\begin{array}{l}\text { Widespread, weaker in forebrain neuroepithelium; upregulated in } \\
\text { rhombomeres } 4,7 \text { and spinal cord }\end{array}$ & $\begin{array}{l}\text { Ruberte et al., 1991; Ruberte et al., } 1993 \\
\text { (mouse) }\end{array}$ \\
\hline Rarb & $\begin{array}{l}\text { Rhombomere } 7 \text { and spinal cord; head and branchial arch mesenchyme (except } \\
\text { mandibular arch); foregut endoderm and mesenchyme; mesonephros, } \\
\text { lateral plate mesoderm; proximal limb bud mesenchyme }\end{array}$ & $\begin{array}{l}\text { Smith and Eichele, } 1991 \text { (chick); Dollé et } \\
\text { al., 1989; Ruberte et al., 1991; Ruberte } \\
\text { et al., } 1993 \text { (mouse) }\end{array}$ \\
\hline Rarg & $\begin{array}{l}\text { Primitive streak; frontonasal and 1st branchial arch mesenchyme; limb bud } \\
\text { mesenchyme; trunk and caudal neural plate (transient), presomitic and tail } \\
\text { bud mesoderm; precartilaginous cell populations }\end{array}$ & $\begin{array}{l}\text { Abu-Abed et al., 2003; Dollé et al., 1989; } \\
\text { Ruberte et al., 1991; Ruberte et al., } \\
1990 \text { (mouse) }\end{array}$ \\
\hline Rxra & $\begin{array}{l}\text { Widespread/ubiquitous; upregulated in posterior hindbrain and dorsal spinal } \\
\text { cord (chick) }\end{array}$ & $\begin{array}{l}\text { Hoover and Glover, } 1998 \text { (chick); Dollé et } \\
\text { al., } 1994 \text { (mouse) }\end{array}$ \\
\hline$R x r b$ & Widespread/ubiquitous & Dollé et al., 1994 (mouse) \\
\hline$R x r g$ & $\begin{array}{l}\text { Cranial and peripheral nervous system neural crest (chick); myotomes, } \\
\text { developing muscle (mouse) }\end{array}$ & $\begin{array}{l}\text { Rowe and Brickell, } 1995 \text { (chick); Dollé et } \\
\text { al., } 1994 \text { (mouse) }\end{array}$ \\
\hline
\end{tabular}

*The stages covered correspond to embryogenesis, roughly from the onset of gastrulation to somitogenesis/early organogenesis. Expression at earlier stages (preimplantation stages for mammals, blastula/morula) or during later organogenesis (foetal development in mammals) is not summarised.

${ }^{\ddagger}$ Relevant references are quoted for two species (chick and mouse), with observations made only in one species indicated among the list of main expression sites.

In the nucleus, RAR/RXR dimers bind to DNA motifs known as RAREs. RAREs consist of a direct repeat of a core hexameric sequence $5^{\prime}-(\mathrm{A} / \mathrm{G}) \mathrm{G}(\mathrm{G} / \mathrm{T}) \mathrm{TCA}-3^{\prime}$ or of the more relaxed $5^{\prime}-$ $(\mathrm{A} / \mathrm{G}) \mathrm{G}(\mathrm{G} / \mathrm{T})(\mathrm{G} / \mathrm{T})(\mathrm{G} / \mathrm{C}) \mathrm{A}-3^{\prime}$ motif, separated by 1,2 or 5 bp (see Balmer and Blomhoff, 2002). RAR/RXRs can bind RAREs even in the absence of ligand, thereby recruiting co-repressor complexes and maintaining target gene repression (Fig. 3). In the presence of ligand, a conformational change leads to the release of corepressors and the recruitment of co-activator complexes. These induce chromatin remodelling, which decompacts the chromatin and facilitates the assembly of the transcription pre-initiation complex. A recent whole-genome chromatin immunoprecipitationsequencing (ChIP-Seq) study performed in ES cells suggested that the presence of RA might also induce de novo RAR/RXR binding to numerous RAREs that are not bound by unliganded receptors (Mahony et al., 2011).

Numerous RAR target genes have been identified (see Balmer and Blomhoff, 2002), including genes from within the retinoid pathway, such as Rarb, Crbp1/2 (Rbp1/2), Crabp1/2 and Cyp26al (see Box 1 and Table 3). Also, several members of the Hox gene family, including Hoxa1, Hoxb1, Hoxb4 and Hoxd4, harbour RAREs, the function of which has been demonstrated in vivo (reviewed by Marshall et al., 1996). The number of putative target genes is increasing rapidly through novel technologies. Recently, for example, Luijten et al. used rodent whole-embryo culture combined with RA treatments and performed microarray analysis to identify genes that were up- or downregulated by RA (Luijten et al., 2010). It should also be stressed that some of the effects of RA might involve binding to other nuclear receptors, such as PPAR $\beta / \gamma$ (Schug et al., 2007).

\section{RA functions during development RA signalling during hindbrain development}

Segmentation and patterning of the hindbrain are regulated by $\mathrm{RA}$

Numerous studies have focused on the embryonic hindbrain as an experimental paradigm for understanding RA regulatory effects. Hindbrain development involves the generation of seven to eight neuroepithelial compartments or rhombomeres (Fig. 4A), each with a distinct identity according to its anteroposterior (A-P) position (Kiecker and Lumsden, 2005). This segmentation underlies several events required for development of the brain stem, inner ear, branchial arches, and even the heart and large vessels, which are colonised by hindbrain-derived neural crest cells. Several Hox genes, according to their spatially restricted expression patterns, are required for the growth and/or positional identity of specific 
Table 2. Loss-of-function phenotypes resulting from targeted inactivation of retinoid signalling pathway genes in mice

\begin{tabular}{|c|c|c|c|}
\hline Gene(s)* & Stage of lethality & Loss-of-function phenotype & Main references \\
\hline Adh1 & Viable & Postnatal increase in vitamin A toxicity & $\begin{array}{l}\text { Deltour et al., 1999b; Molotkov et } \\
\text { al., 2002b }\end{array}$ \\
\hline Adh5 & Postnatal & Growth deficiency, vitamin A toxicity & $\begin{array}{l}\text { Deltour et al., 1999b; Molotkov et } \\
\text { al., 2002a; Molotkov et al., } \\
\text { 2002b }\end{array}$ \\
\hline Adh7 & Viable & Sensitivity to vitamin A deficiency & $\begin{array}{l}\text { Deltour et al., 1999a; Deltour et } \\
\text { al., 1999b }\end{array}$ \\
\hline Rdh5 & Viable & Vision: delay in dark adaptation & Driessen et al., 2000 \\
\hline Rdh10 & E10.5-14.5 & $\begin{array}{l}\text { Small optic vesicles/eyes; abnormal hindbrain and posterior } \\
\text { branchial arches; abnormal heart tube; small forelimb buds; } \\
\text { defects in organogenesis (lung, gut, pancreas, kidney) }\end{array}$ & $\begin{array}{l}\text { Cunningham et al., 2011; Sandell } \\
\text { et al., 2007; Rhinn et al., } 2011\end{array}$ \\
\hline Raldh1 & Viable & No abnormality reported & Fan et al., 2003; Matt et al., 2005 \\
\hline Raldh2 & E9.5-10.5 & $\begin{array}{l}\text { Hypoplastic optic vesicles; abnormal hindbrain } \\
\text { ('anteriorisation'), lack of posterior branchial arches; } \\
\text { impaired heart looping and chamber differentiation; } \\
\text { truncation of body axis, asymmetry in somite formation; } \\
\text { absence of limb buds; defects in organogenesis (lung, gut, } \\
\text { pancreas, kidney) }\end{array}$ & $\begin{array}{l}\text { Mic et al., 2002; Niederreither et } \\
\text { al., 1999; Niederreither et al., } \\
\text { 2001; Niederreither et al., 2000; } \\
\text { Ribes et al., 2009; Ribes et al., } \\
\text { 2006; Sirbu and Duester, 2006; } \\
\text { Vermot et al., } 2005\end{array}$ \\
\hline Raldh3 & Neonatal & $\begin{array}{l}\text { Shortening of ventral retina; nasal abnormality (choanal } \\
\text { atresia); altered GABAergic neuronal differentiation in } \\
\text { forebrain basal ganglia }\end{array}$ & $\begin{array}{l}\text { Chatzi et al., 2011; Dupé et al., } \\
\text { 2003; Matt et al., 2005; } \\
\text { Molotkov et al., } 2006\end{array}$ \\
\hline Cyp26a1 & Neonatal & $\begin{array}{l}\text { Abnormal hindbrain ('posteriorisation'); truncation of } \\
\text { posterior body, sometimes with sirenomelia ('mermaid-like } \\
\text { tail'); vertebral transformations }\end{array}$ & $\begin{array}{l}\text { Abu-Abed et al., 2001; Sakai et } \\
\text { al., } 2001\end{array}$ \\
\hline Cyp26b1 & Neonatal & $\begin{array}{l}\text { Limb defects (abnormal distal skeleton and cartilage } \\
\text { maturation); craniofacial abnormalities (reduced maxilla and } \\
\text { mandible, cleft palate); gonadal abnormalities (premature } \\
\text { meiosis, apoptosis of male germ cells) }\end{array}$ & $\begin{array}{l}\text { Bowles et al., 2006; MacLean et } \\
\text { al., 2009; MacLean et al., 2007; } \\
\text { Yashiro et al., } 2004\end{array}$ \\
\hline Cyp26c1 & Viable & No abnormality reported & Uehara et al., 2007 \\
\hline Сур26а 1;Сур26с1 & E9.5-10.5 & $\begin{array}{l}\text { Reduced forebrain and midbrain, hindbrain expansion; } \\
\text { deficiency in cranial neural crest }\end{array}$ & Uehara et al., 2007 \\
\hline Rara & $\begin{array}{l}\text { Postnatal } \\
\text { (variable) }\end{array}$ & $\begin{array}{l}\text { Growth deficiency; vertebral transformations/abnormalities; } \\
\text { malformed laryngeal cartilages; webbed digits (variable); } \\
\text { male sterility (degeneration of testis germinal epithelium) }\end{array}$ & $\begin{array}{l}\text { Ghyselinck et al., 1997; Lufkin et } \\
\text { al., } 1993\end{array}$ \\
\hline Rarb & Viable & $\begin{array}{l}\text { Growth deficiency; vertebral transformations/abnormalities; } \\
\text { ocular abnormality (retrolenticular membrane); locomotor } \\
\text { behavioural defects }\end{array}$ & $\begin{array}{l}\text { Ghyselinck et al., 1997; Krezel et } \\
\text { al., } 1998\end{array}$ \\
\hline Rarg & $\begin{array}{l}\text { Postnatal } \\
\text { (variable) }\end{array}$ & $\begin{array}{l}\text { Growth deficiency; vertebral transformations/abnormalities; } \\
\text { malformed laryngeal and tracheal cartilages } \\
\text { Webbed digits (variable); abnormal differentiation of } \\
\text { keratinocytes; male sterility (abnormal seminal vesicle and } \\
\text { prostate epithelia) }\end{array}$ & $\begin{array}{l}\text { Chapellier et al., 2002; Ghyselinck } \\
\text { et al., 1997; Lohnes et al., } 1993\end{array}$ \\
\hline Rara;Rarb & Neonatal & $\begin{array}{l}\text { Abnormal hindbrain patterning (abnormal r5-r7); } \\
\text { absence/abnormality of posterior branchial arch derivatives } \\
\text { (thymus, parathyroids) and salivary glands; heart outflow } \\
\text { tract and large vessel abnormalities; severe laryngeal/tracheal } \\
\text { abnormalities; lung hypoplasia, lack of oesophagotracheal } \\
\text { separation; kidney and female genital tract abnormalities }\end{array}$ & $\begin{array}{l}\text { Batourina et al., 2001; Dupé et } \\
\text { al., 1999; Ghyselinck et al., 1997; } \\
\text { Lohnes et al., 1994; Mendelsohn } \\
\text { et al., } 1994\end{array}$ \\
\hline Rara;Rarg & $\begin{array}{l}\text { E12.5 to } \\
\text { neonatal }\end{array}$ & $\begin{array}{l}\text { Abnormal hindbrain patterning ('anteriorisation'); } \\
\text { absence/abnormality of posterior branchial arch derivatives } \\
\text { (thymus, parathyroids) and salivary glands; eye defects } \\
\text { (retinal coloboma, absence of lens); heart outflow tract and } \\
\text { large vessel abnormalities, myocardial hypoplasia; severe } \\
\text { laryngeal/tracheal abnormalities; craniofacial and limb } \\
\text { skeletal defects; kidney, male and female genital tract } \\
\text { abnormalities }\end{array}$ & $\begin{array}{l}\text { Ghyselinck et al., 1997; Lohnes et } \\
\text { al., 1994; Mendelsohn et al., } \\
\text { 1994; Wendling et al., } 2001\end{array}$ \\
\hline Rxra & E13.5-16.5 & $\begin{array}{l}\text { Heart outflow tract and large vessel abnormalities, myocardial } \\
\text { hypoplasia; eye defects (shortening of ventral retinal } \\
\text { abnormal cornea); placental defect (disorganisation of } \\
\text { labyrinthine zone) }\end{array}$ & $\begin{array}{l}\text { Gruber et al., 1996; Kastner et al., } \\
\text { 1994; Merki et al., 2005; Sapin } \\
\text { et al., 1997; Sucov et al., } 1994\end{array}$ \\
\hline Rxrb & $\begin{array}{l}\text { Partial } \\
\text { perinatal } \\
\text { lethality }\end{array}$ & $\begin{array}{l}\text { Male sterility (abnormal Sertoli cells, impaired spermatozoid } \\
\text { production) }\end{array}$ & Kastner et al., 1996 \\
\hline Rxrg & Viable & Behavioural and depression-like defects & $\begin{array}{l}\text { Krezel et al., 1998; Krzyzosiak et } \\
\text { al., } 2010\end{array}$ \\
\hline$R \times r a ; R x r b$ & E9.5-10.5 & $\begin{array}{l}\text { Truncation of posterior body; abnormal nasal region and } \\
\text { posterior branchial arches; abnormal heart tube; placental } \\
\text { defect (absence of labyrinthine zone) }\end{array}$ & Wendling et al., 1999 \\
\hline
\end{tabular}


A
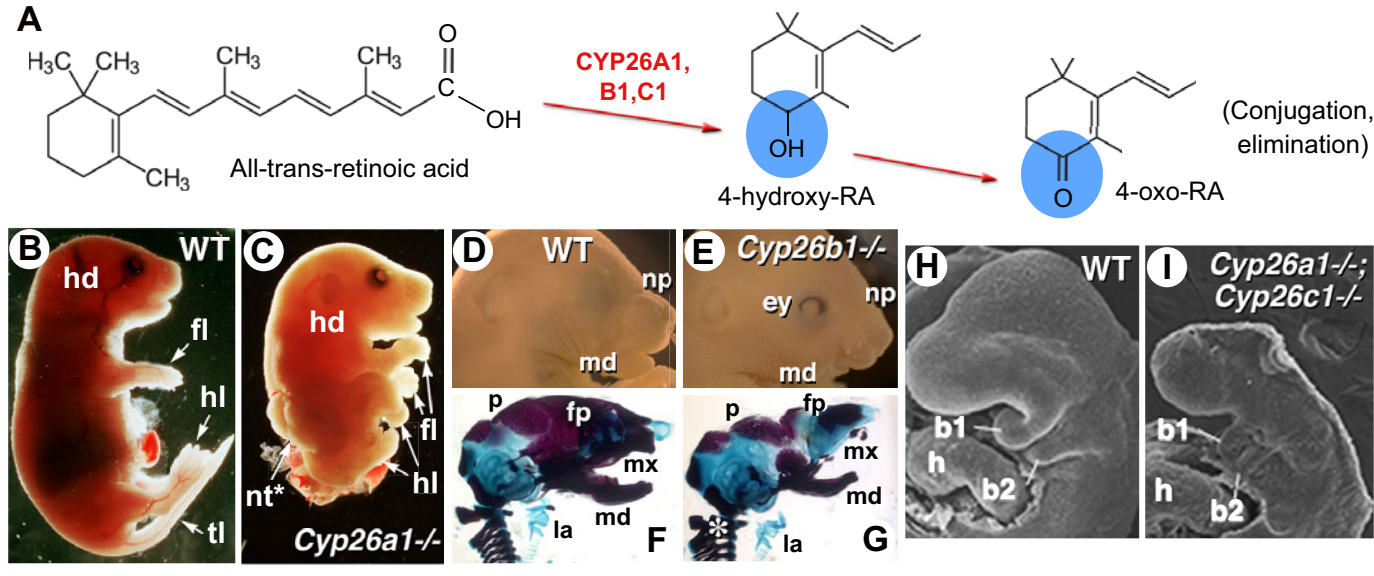

Fig. 2. RA metabolism and degradation. (A) All-trans-retinoic acid is converted by CYP26 enzymes (CYP26A1, CYP26B1 and CYP26C1) into the more polar metabolites 4-hydroxy-RA and 4-oxo-RA, which eventually become conjugated (mainly as glucuronates) and are eliminated (by excretion). (B-I) Phenotypes of null mutants for Cyp26a1 (C) and Cyp26b1 (E,G) and of the compound Cyp26a1;Cyp26c1 mutant (I), compared with their wild-type (WT) littermates (B,D,F,H). At prenatal stages (E18.5), Cyp26a1 $1^{-/}$mutants have an open neural tube (nt*) and severe posterior body truncation with abnormal positioning of the hindlimbs ( $\mathrm{hl}$ ). Cyp26b1 $1^{-/-}$mutants exhibit a spectrum of facial, laryngeal and vertebral abnormalities. Compound inactivation of Cyp26a1 and Cyp26c1 is early embryonic lethal and leads to dramatic head truncation, with associated hindbrain and neural crest alterations. F, G show skeletal preparations visualised by Alizarin Red/Alcian Blue staining; H,I are scanning electron micrographs. b1, b2,

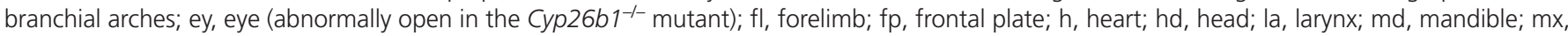
maxillary; $\mathrm{np}$, nasal process; $\mathrm{p}$, parietal bone; $\mathrm{tl}$, tail. The asterisk in $\mathrm{G}$ indicates abnormally fused cervical vertebrae. Reproduced with permission: B,C (Abu-Abed et al., 2001); D-G (MacLean et al., 2009); H,I (Uehara et al., 2007).

rhombomeres (reviewed by Marshall et al., 1996; Rijli et al., 1998). Treatment of pregnant mice or rats with excess RA leads to teratogenic changes in the hindbrain (Morriss, 1972). Interestingly, RA exposure at late gastrula/early neurula stages increases hindbrain size at the expense of other brain regions (Avantaggiato et al., 1996), whereas RA treatment at later stages specifically leads to a 'posteriorisation' of rhombomeres (r) 2-3 to an r4-r5 identity (see Marshall et al., 1996).

Evidence that endogenous retinoids are required for hindbrain patterning was found in vitamin A-deficient (VAD) quail embryos, in which the caudal hindbrain region (r4-r8) was misspecified into an enlarged $\mathrm{r} 3$, and more anterior rhombomeres expanded posteriorly (Fig. 4B) (Gale et al., 1999). Region-specific effects of

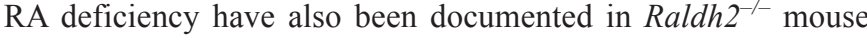
mutants, which lack rhombomeric segmentation and exhibit a severe reduction of the posterior hindbrain. Strikingly, the expression of genes normally restricted to r3-r4 [such as Hoxb1, Krox20 (Egr2)] spreads posteriorly in these mutants, whereas expression of r5-r7 determinants (Mafb, Hoxd4) is reduced or abolished (Fig. 4C) (Niederreither et al., 2000). These patterning defects have dramatic consequences for related developmental events, such as inner ear patterning, neural crest migration (leading to a lack of development of all branchial arches except for the first one), or neurite/cranial nerve differentiation. In zebrafish raldh2 mutants, a similar hindbrain anteriorisation is described (Begemann et al., 2001; Grandel et al., 2002). These results led to the conclusion that RA produced by RALDH2 in somitic mesoderm diffuses towards the hindbrain, acting as a classical 'vertical' signal to control patterning and regulate the expression of posterior rhombomeric determinants.

As RARs have partly redundant functions, hindbrain abnormalities are found only when at least two receptors are inactivated in combination. Interestingly, such compound inactivations have different outcomes on hindbrain patterning. Rara $^{-/} ; \mathrm{Rarg}^{-/-}$mutants display severe malformations similar to

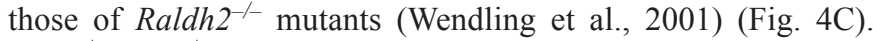
$\mathrm{Rara}^{-/-} ; \mathrm{Rarb}^{-/-}$mutants show a different phenotype, in which only r5-r7 have abnormal boundaries, and genes normally restricted to r5-r6 spread posteriorly at the expense of r7 markers (Fig. 4D) (Dupé et al., 1999). Exposure of cultured wild-type embryos to BMS493, a pan-RAR antagonist, at early somite stages phenocopied the $\mathrm{Rara}^{-/} ; \mathrm{Rarg}^{-/-}$hindbrain defects, whereas an earlier treatment at the beginning of gastrulation yielded an $\mathrm{Rara}^{-/-}$; $\mathrm{Rarb}^{-/-}$-like phenotype (Wendling et al., 2001). This indicates that RAR $\alpha$ and/or RAR $\gamma$ mediates the early effects of RA on hindbrain patterning, whereas RAR $\beta$ functions later in development in setting up the size and caudal boundary of the r5/r6 territory.

Importantly, Cyp26 genes display differential, rhombomerespecific expression patterns. Cyp26al loss-of-function leads to subtle patterning defects, with an enlarged $\mathrm{r} 4$ and partial transformation of r3 to an r4-like identity (Abu-Abed et al., 2001; Sakai et al., 2001) (Fig. 4E). Hindbrain abnormalities were not observed in Cyp26b1 $1^{-/-}$or Cyp26c1 $1^{-/-}$mutants, although compound Cyp26a1;Cyp26c1 inactivation leads to severe defects (lack of segmentation and posteriorisation of the prospective $\mathrm{r} 1-\mathrm{r} 4$ region) (MacLean et al., 2009; Uehara et al., 2007) (Fig. 4F). As described below, CYP26 enzymes are likely to act in a concerted manner to control RA diffusion and maintain specific pre-rhombomeric territories in an RA-free state.

\section{The hindbrain: an experimental paradigm to study RA morphogenetic gradients}

The striking effects of both retinoid excess and retinoid deficiency on hindbrain patterning have stimulated research into the underlying mechanisms and modes of RA action. Almost 25 years ago, RA was identified as the first candidate vertebrate morphogen, following the discovery of uneven concentrations of RA across the developing chick limb bud (Thaller and Eichele, 1987). Morphogens are signalling molecules that act non-cell- 


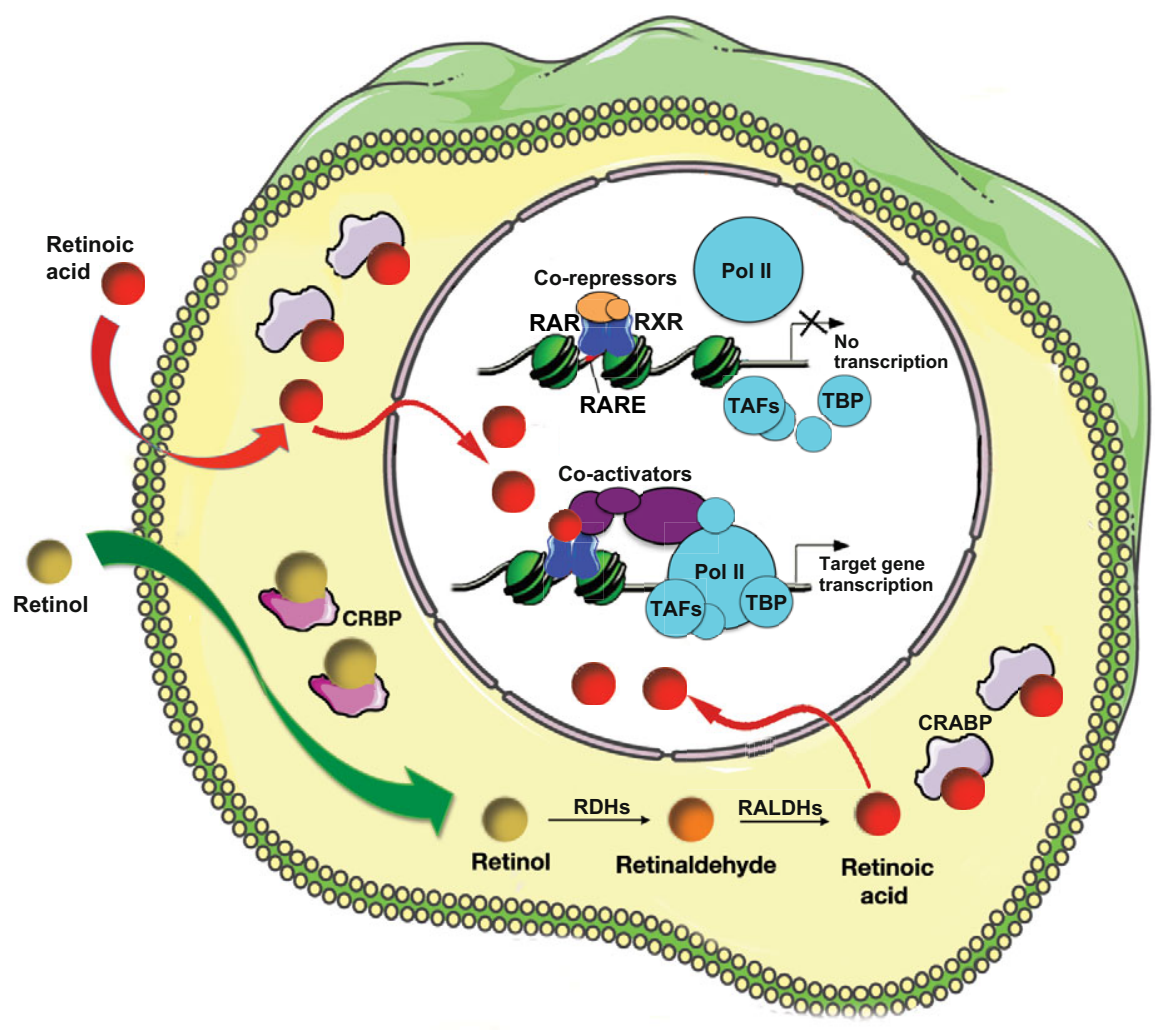

Fig. 3. Summary of the RA signalling

pathway. RA, synthesized intracellularly from circulating retinol or diffusing from an adjacent cell (curved red arrow), eventually reaches the nucleus. Cellular retinoic acid-binding proteins (CRABPs) may be involved in this transfer. Cellular retinol-binding proteins (CRBPs) may help present retinol to retinol dehydrogenases (RDHs). Dimers of RA receptors (RARs) and retinoid $X$ receptors (RXRs), termed RAR/RXR, are able to bind to RA-response elements (RAREs) in their target genes in the absence of ligand, interacting with protein complexes (corepressors) that stabilise the chromatin nucleosomal structure and prevent access to the promoter. Upon RA binding, a conformational change in the helicoidal structure of the RAR ligand-binding domain changes its protein-protein interaction properties, releasing the co-repressors and recruiting co-activator complexes that destabilise the nucleosomes and/or facilitate assembly of the transcription pre-initiation complex, which contains RNA polymerase II (Pol II), TATA-binding protein (TBP) and TBPassociated factors (TAFs). autonomously in a concentration-dependent fashion to assign positional identities to fields of cells (Wolpert, 2011). Over the last 10 years, several groups have tried to gain insights into how the spatial distribution of RA is regulated. Below, we discuss the 'classical' and newer aspects of this regulation and establishment of possible RA gradient(s), the main emerging concept being that several enzymatic activities (e.g. of RDHs and CYP26s) are required in addition to RALDHs to dynamically control and shape RA distributions within the embryo.

Does RA match the definition of a morphogen? As a small lipophilic molecule (Fig. 1) it is able to diffuse across cell membranes. Furthermore, it is soluble in water up to $\sim 200 \mathrm{nM}$ (Szuts and Harosi, 1991), i.e. within its physiological concentration range, so diffusion gradients might also occur in the extracellular space. Within the hindbrain, RA can control gene expression in a concentration-dependent manner, as demonstrated by concentration-dependent effects of RA treatments (e.g. Durston et al., 1989). Treatment of chick or zebrafish embryos with the RA antagonist BMS493 showed that more posterior rhombomere boundaries require progressively higher concentrations of RA for their correct positioning (Dupé and Lumsden, 2001; Maves and Kimmel, 2005). The RA source for hindbrain patterning is local and corresponds to presomitic mesoderm (PSM) and somites expressing Raldh2 near the caudal hindbrain (Fig. 5). These observations might support a role for RA acting as a diffusible morphogen in the pre-segmented hindbrain, perhaps diffusing from its mesodermal source via cell-cell contacts. Unlike other established morphogens [e.g. FGF8 or sonic hedgehog (SHH)], a gradient for RA has never been demonstrated, mainly owing to technical limitations. Recently, White et al. (White et al., 2007) visualised RA indirectly in zebrafish using a fluorescent marker under the control of RAREs (rare:yfp). In transgenic embryos, YFP expression was clearly graded from posterior to anterior regions of the hindbrain. This expression is lost in RA-deficient mutant embryos, but can be restored by the prior transplantation of cells overexpressing Raldh2 into somitic mesoderm. In most cases, the rescue spanned the width of the neural tube along a six-cell (70 $\mu \mathrm{m}$ ) diameter (White et al., 2007).

In another zebrafish study, Maves and Kimmel (Maves and Kimmel, 2005) reported a sequential induction of RA target genes, and showed that posteriorly expressed genes do not require longer exposure, but require higher levels of RA for induction than anteriorly expressed genes. This suggests that the RA gradient would increase over time, and that the high concentrations needed to activate posterior genes are only reached later during hindbrain development. The authors proposed a model in which the hindbrain needs a temporally increasing source of RA to define rhombomere identities sequentially (Fig. 5A).

The observation that Cyp26 genes show rhombomeric-specific expression patterns drove the idea that degradation might be involved in shaping RA distribution. In a mouse study, Sirbu et al. correlated the dynamics of Hoxb1 expression, from its onset to its restriction in $\mathrm{r} 4$, with the dynamic expression of Cyp26 genes (Sirbu et al., 2005). They proposed a 'shifting boundaries' model in which the anterior boundaries of rhombomere-specific genes are fixed by the posterior limit of CYP26 activity at the time of their onset of expression. Hernandez et al. obtained consistent results in zebrafish, and elaborated a 'gradient-free' model, in which RA degradation by CYP26 enzymes determines progressively more posterior limits of RA-dependent gene expression in a stepwise manner (Hernandez et al., 2007). All three CYP26s would thus function to establish three sequential boundaries in RA responsiveness, i.e. pre-r3/r4, r4/r5 and r6/r7 (Fig. 5B).

As Cyp26al is under the control of RA signalling, a more subtle role for RA degradation has been proposed by White and colleagues (White et al., 2007; White and Schilling, 2008). Their model (Fig. 5C), in which CYP26A1 plays a central role in modulating RA levels dynamically, can reconcile the various 
Table 3. Examples of genes containing functional and/or evolutionarily conserved RA-response elements

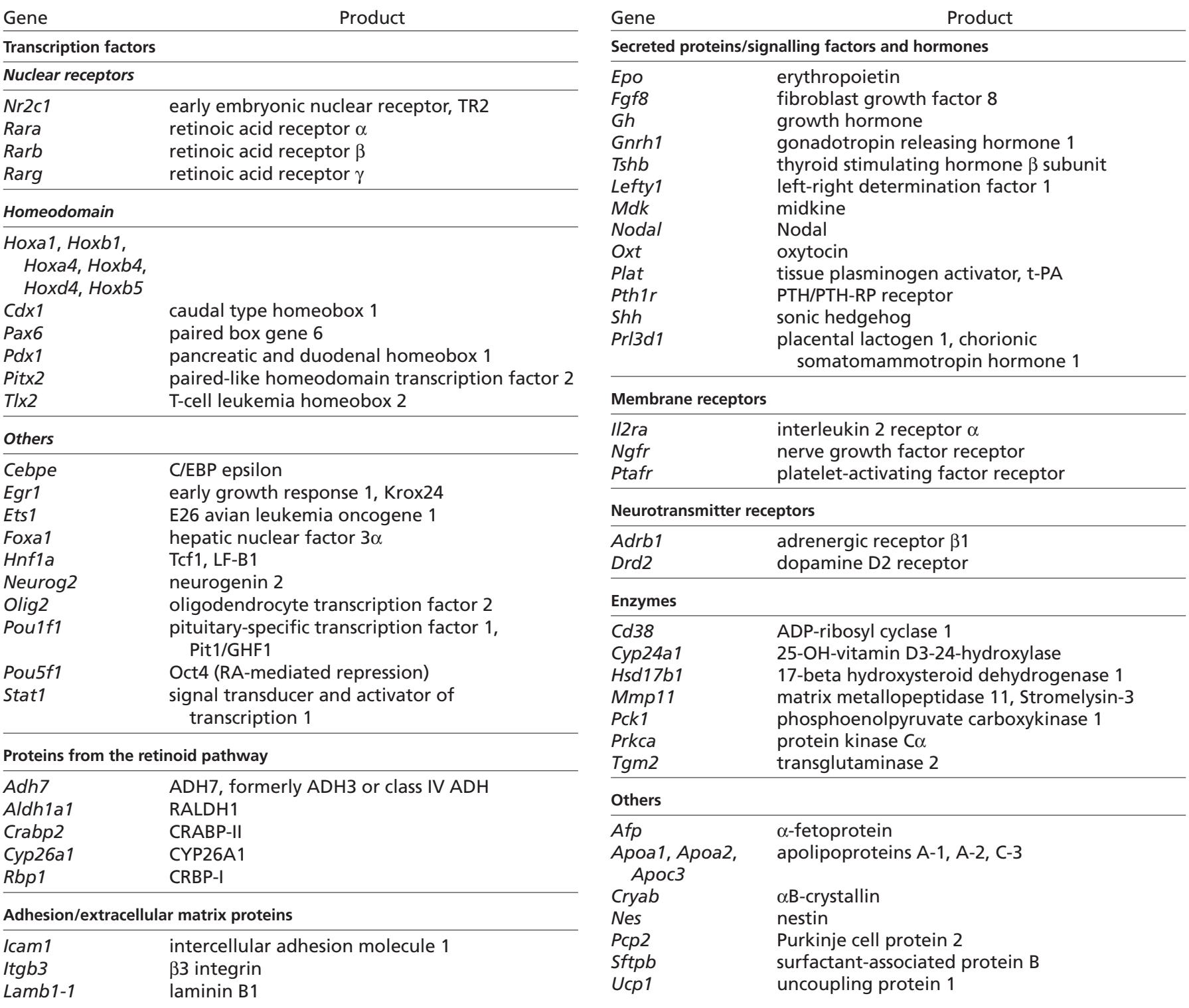

The list is organised according to the types of proteins encoded and is by no means exhaustive. For detailed lists of RA-responsive genes from which these data were mainly compiled, see Balmer and Blomhoff (Balmer and Blomhoff, 2002; Balmer and Blomhoff, 2005).

observations described above. Using bead implantation, the authors showed that FGF signalling acts indirectly by inhibiting RAdependent activation of Cyp26al expression. By computational analysis, they showed that RA gradients can be influenced by interacting feedback (RA signalling then inducing RA degradation) and feedforward (FGF signalling then repressing RA degradation) effects. The feedforward effects of FGFs couple the shape of the RA gradient to that of the FGF gradient. They argue that this makes the gradient stable to fluctuations in RA synthesis, but also over an expanding field of cells.

One aspect that should be addressed is regulation at the level of the source of RA. Studies in Xenopus proposed an alternative mode of RA gradient formation based on cooperation between RDH10 and RALDH2 (Strate et al., 2009). RDH10 produces retinaldehyde in the anterior cervical mesoderm and ventral hindbrain that diffuses posteriorly, where RALDH2 converts it into RA. Highest levels of RA would thus be produced at the anterior front of
RALDH2 expression, where retinaldehyde concentration is highest, with decreasing concentrations observed posteriorly (Fig. 5D). This peak of RA would move posteriorly concomitant with the translocation of the RDH10 and RALDH2 expression domains, shifting the peak of the gradient from the hindbrain/spinal cord boundary to within the spinal cord. Further studies are required to address the significance of such cooperative effects in the hindbrain or in other morphogenetic fields. It was shown recently that Raldh2 expression is under the transcriptional control of a ternary complex that includes Hox, Pbx and Meis proteins. Both $P b x 1 ; P b x 2$ and Hoxal;Pbxl compound mutant mice show reduced mesodermal Raldh2 expression (Vitobello et al., 2011). These authors show that HOXA1-PBX1/2-MEIS2 directly binds a regulatory element required to maintain normal Raldh2 expression. Thus, in the hindbrain, Hox proteins may regulate their own boundaries by controlling RALDH2 levels, thus contributing to shaping the RA gradient produced. 


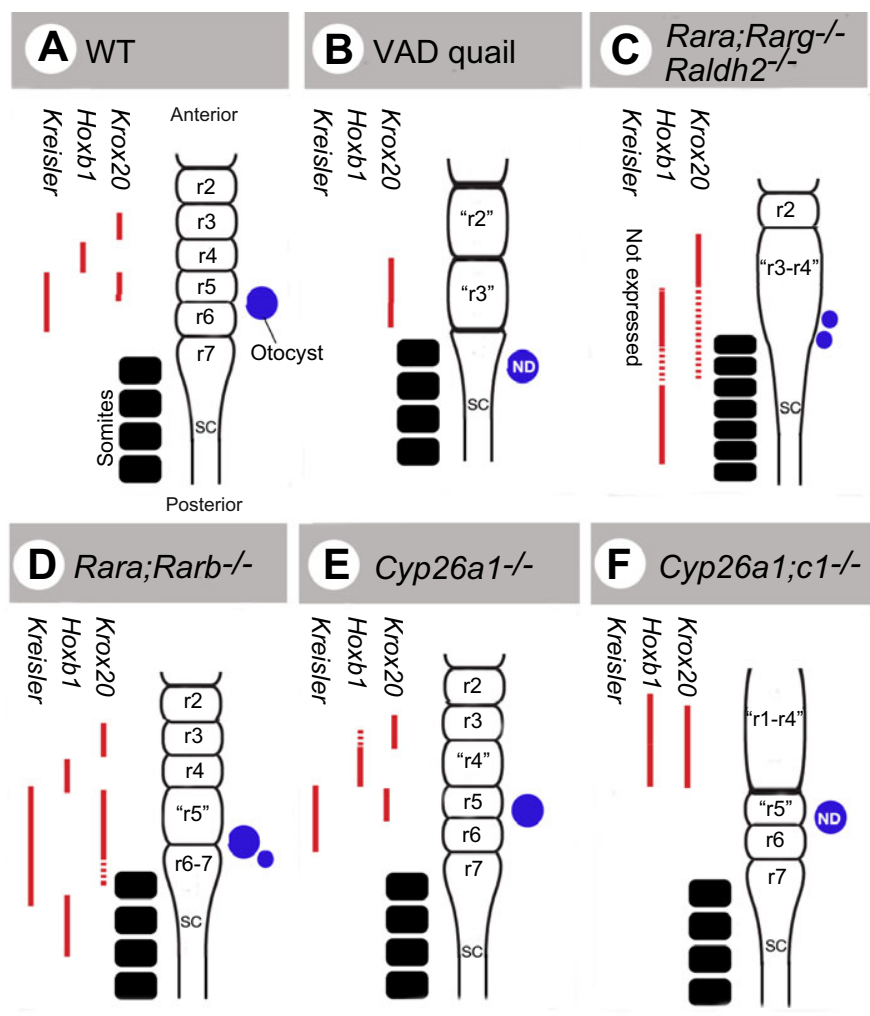

Fig. 4. Hindbrain abnormalities in animal models with altered RA signalling. (A) The hindbrain rhombomeric structure in a wild-type (WT) embryo, highlighting rhombomeres 2-7 (r2-r7) with adjacent somites (black) and otocyst (blue) also shown. Pre-segmental/segmental expression patterns of three key rhombomeric markers [Kreisler (Mafb), Hoxb1, Krox20] are depicted (red bars; dashed bars indicate patchy or illdefined expression domains). (B-F) Alterations in hindbrain segmentation and molecular patterning are illustrated in various animal models with endogenous deficiency in RA signalling: (B) vitamin A-deficient (VAD)

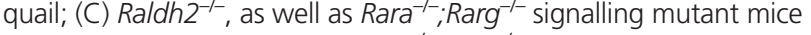
(lacking RAR $\alpha$ and RAR $\gamma$ ); (D) Rara ${ }^{-1} ;$ Rarb $^{-/}$mice (lacking RAR $\alpha$ and RARß); (E) Cyp26a $1^{-1-}$ mice; and (F) Cyp26a $1^{-1-}$;Cyp26 $\mathrm{C1}^{-/-}$mice. Abnormal (enlarged, non-segmented and/or abnormally patterned) rhombomeres are indicated by quotation marks. Otocyst abnormalities were not determined (ND) in some models. SC, spinal cord.

\section{RA functions during forebrain development}

Whereas many studies have investigated RA functions in the developing hindbrain, other aspects of brain development remain less explored. Initial studies using the chick system in which an RAR/RXR antagonist was delivered by bead implantation (Schneider et al., 2001), or using the VAD quail model (Halilagic et al., 2003), indicated a role for RA in A-P patterning of the embryonic forebrain and cell survival in the telencephalon (the anteriormost forebrain derivative). Moreover, RA was suggested to specify an intermediate character within the telencephalon, acting in combination with SHH to impart ventral identity and with Wnts/FGFs to impose a dorsal character (Marklund et al., 2004).

Two Raldh genes are differentially activated during early embryonic head and forebrain development. Raldh2 is transiently expressed in the rostral neural plate and optic vesicles, whereas Raldh3 is expressed slightly later in the surface ectoderm overlying the anterior forebrain. Studies of murine Raldh2/Raldh3 loss-offunction mutants only partly supported the avian experimental data. Using a RARE-containing reporter transgene it was found that
Raldh2 inactivation ablates all RA activity in the forebrain neuroepithelium (Mic et al., 2004a; Ribes et al., 2006). Raldh2 $2^{-/}$ embryos exhibit defective growth and morphogenesis of the optic vesicle, which is an evagination of the forebrain neuroepithelium and precursor of the retina (Mic et al., 2004a). Ribes et al. reported additional forebrain deficiencies in Raldh $2^{-/}$mutants, with decreased cell proliferation and altered expression of several ventral determinants, including SHH-responsive genes (Ribes et al.,

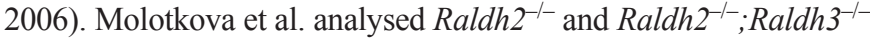
compound mutants and questioned an early function of RA in forebrain based on their observation of normal expression patterns of genes including $\mathrm{Fg} f 8$ and Meis2 (Molotkova et al., 2007). Thus, whether RA plays crucial roles apart from regulating optic vesicle development remains controversial and is a difficult issue to address with the available (embryonic lethal) Raldh-null mouse models. An alternative approach to inhibit RA signalling consists of expressing a dominant-negative receptor (DN-RAR $\alpha$ ) in the embryonic telencephalon (using the Cre-lox system for tissuespecific expression). This approach also led to a decrease in cell proliferation and to increased cell death in telencephalic progenitor populations (Rajaii et al., 2008). Furthermore, an abnormal distribution of Islet1-expressing cells was found in the ventral telencephalon, with Islet $1^{+}$cells present in the medial ganglionic eminences (MGEs) instead of being restricted to the lateral ganglionic eminences (LGEs), suggesting a role for RA in the specification of progenitor cell populations.

Retinoid signalling may influence specific progenitor populations at later stages of forebrain development, although these functions remain poorly characterised. Smith et al. (Smith et al., 2001) first suggested that RA could be a diffusible signal regulating neurogenesis in the cerebral cortex, based on the observation that Raldh2 - and to a lesser extent Raldh1 - is expressed in the developing meningeal cell layer from E13.5 to postnatal stages. RA produced by meningeal cells could thus diffuse within the neuroepithelium, where it may influence progenitor cell proliferation or differentiation and/or radial migration along cortical layers. Meningeally produced RA may regulate neurogenesis in other brain regions at later developmental stages (Zhang et al., 2003). A new player came from the recent work of Siegenthaler et al. (Siegenthaler et al., 2009). RDH10, which acts upstream of RALDHs, is also expressed in the developing meninges (Romand et al., 2008) and, while studying Foxcl mutant mice that exhibit defective forebrain meningeal formation, Siegenthaler et al. showed decreased Raldh2 and Rdh10 expression in the affected meninges, and found that all-trans-RA treatment improved cortical development both in vivo and in an explant culture system. Chatzi et al. (Chatzi et al., 2011) challenged these results and the hypothesis of a role for meningeal RA. These authors analysed Raldh2 $2^{--}$mutants at E14.5 after maternal RA rescue, and reported no change in cell proliferation or in the overall organisation of the cortical layers, although the meningeal layers lacked RA activity as observed with a reporter transgene. This issue will need to be resolved by more in-depth studies and might require the generation of additional murine models with tissue-specific ablation of RA synthesis in meninges. Currently, the only unequivocal role of RA in the forebrain at the mid to late developmental stages relates to the differentiation of GABAergic striatal projection neurons and interneurons migrating to olfactory bulb and cortex, and involves RALDH3 activity in the LGE subventricular zone (Chatzi et al., 2011; Molotkova et al., 2007). Furthermore, it is becoming clear that endogenous RA functions are likely to persist in adult neuronal populations (see Box 3). 


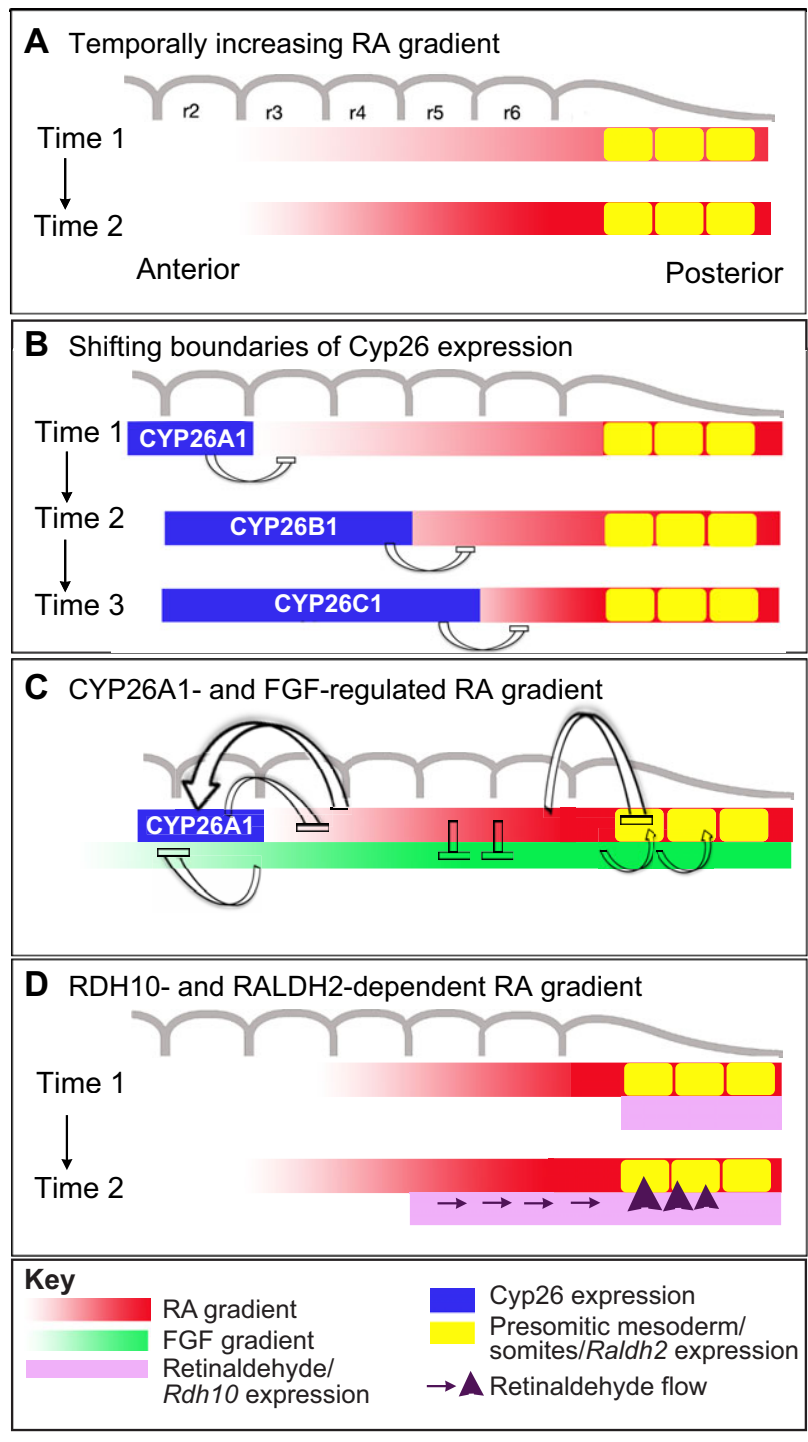

\section{RA actions in foregut derivatives}

RA signalling has numerous other functions during early embryogenesis. We briefly discuss how these functions may correlate with gradients of activity and/or diffusion between cell layers, first focusing on the branchial apparatus and then the lungs and pancreas. Details of RA functions in other organ systems can be found in other reviews (Duester, 2008; Niederreither and Dollé, 2008).

\section{RA signalling in the branchial apparatus}

Branchial arches are segmental structures that develop along the embryonic foregut endoderm. They are colonised by segmental $\mathrm{mid} /$ hindbrain neural crest streams and give rise to various derivatives including the hyoid bone, thyroid, parathyroids and thymus, and specific cardiac populations. RA is produced locally by RALDH2, which is expressed in the mesenchyme surrounding the foregut up to a rather sharp boundary at the level of the 4th-6th arches (Niederreither et al., 2003). Analysis of an RA-responsive transgene revealed a more extended area of RA activity, extending up to the posterior edge of the 2 nd arch. Furthermore, this activity was found in both mesenchymal and endodermal cell layers. RALDH2 function in the branchial apparatus was uncovered in Raldh2 $2^{--}$mutants rescued by stage-specific maternal RA supplementation (Niederreither et al., 2003). This supplementation
Fig. 5. Models of sequential RA activity during hindbrain segmentation. Graded distributions of signalling molecules and expression patterns of RA synthesizing and metabolising enzymes are shown. Positive and negative regulatory interactions are depicted as arrows and bars, respectively. These interactions are sequential and initiate at early (pre-segmental) stages in the gastrula/neurula; hence the rhombomere scheme (grey) is only shown to provide positional landmarks. (A) The 'increasing gradient' model proposes that the RA morphogenic gradient is not fixed, but grows steeper with time, specifying rhombomeres sequentially from anterior to posterior. (B) The 'shifting boundary' model posits that localised RA degradation controls and/or refines the time of exposure. Importantly, the expression of CYP26 enzymes is dynamic, thus achieving borders of RA-dependent regulation in a stepwise manner. (C) In the 'degradation-based' model, the RA gradient is shaped by local control of its degradation. Cyp26a1 expression is regulated by the opposing action of two gradients: RA regulating Cyp26a1 positively versus FGF signalling - eventually superseding RA - regulating it negatively. Raldh2 is also controlled by this two-gradient influence, contributing to the regulation of RA production at the source. (D) The most recently proposed model incorporates the action of RDH10, which produces retinaldehyde in the ventral hindbrain and somites that diffuses towards RALDH2-expressing cells. Owing to the dynamics of $R d h 10 / R a / d h 2$ expression, the highest RA levels are produced at the hindbrain/spinal cord boundary, and this peak moves posteriorly as development proceeds. The models shown in A-D are not mutually exclusive and together they are likely to account for the sequential regulatory effects of RA in pre-segmented and segmented hindbrain

partly rescued hindbrain and neural crest defects, unveiling an abnormal branchial phenotype in which all structures derived from the 3rd, 4th and 6th arches failed to develop, including endodermal pouches and aortic arch arteries. Consequently, many of the derivatives of these arches were missing or abnormal at foetal stages. Abnormalities of the aorta and large vessels, which are derived from the aortic arches, were also seen, with a lack of aortic trunk septation (persistent truncus arteriosus) incompatible with postnatal survival. Treatment of early somite stage wild-type embryos with a pan-RAR antagonist (BMS493) led to similar effects on posterior branchial arches (Wendling et al., 2000). Generation of a hypomorphic Raldh2 mutation revealed a particular susceptibility of the branchial region to diminished RA synthesis, as hypomorphic mutants displayed abnormalities that

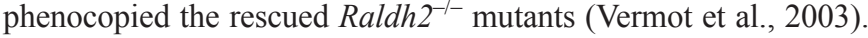
These abnormalities phenocopy a human condition, DiGeorge syndrome, which is caused by chromosomal deletions that affect the genes encoding the transcription factor T-box 1 (TBX1) and the adaptor protein CRKL. Analysis of murine Tbxl/Crkl loss-offunction models revealed locally increased RA signalling due to changes in the Raldh2 and Cyp26a1/Cyp26b1 expression domains (Guris et al., 2006), and a genetic interaction between Raldh2 and Tbxl was recently demonstrated (Ryckebusch et al., 2010). Collectively, these data show that RA acts to pattern posterior branchial arches and their derivatives and implicate the retinoid pathway in the pathogenesis of DiGeorge syndrome.

Consistent molecular abnormalities have been observed in the branchial region of Raldh2 mutants (Niederreither et al., 2003; Vermot et al., 2003) and BMS493-treated cultured embryos (Wendling et al., 2000). Among the affected genes are Hoxal and Hoxb1, which are two RARE-containing genes that are also 


\section{Box 3. Retinoids in the adult brain}

Retinoid functions are likely to persist through postnatal life. Mice mutant for RAR $\beta$ and $R X R \gamma$, two receptors specifically expressed in striatal structures including the caudate putamen and nucleus accumbens (NAC), show reduced locomotor activity and impaired motor performance typical of abnormal striatal function. Importantly, $\mathrm{Rxrg}^{-1-}$ mice show increased despair behaviour and another key symptom of depression (anhedonia), which are both reversed by chronic antidepressant treatment. Adenovirus-mediated re-expression of $R X R \gamma$ within the NAc also reversed these behaviours, clearly demonstrating a postnatal function for RXR $\gamma$ signalling (Krzyzosiak et al., 2010). These findings suggest that altered retinoid signalling could contribute to diseases affecting the nigrostriatal system, such as Parkinson's and Huntington's diseases.

RA may also act in the hippocampus, a key structure for memory processing and emotion. Neurogenesis occurs throughout life in the hippocampal granular zone, a site of high RA activity. Rarb $^{-/-}$and $R \times \mathrm{rg}^{-1-}$ mice are deficient in spatial learning and memory, like vitamin A-deficient (VAD) rats, for which the deficits can be rescued by RA treatment (Bonnet et al., 2008). Altered retinoid signalling may also be involved in the degradation of hippocampal function in aging mice. Some pioneering studies suggest that retinoids might regulate the proliferation and/or differentiation of hippocampal stem cells into functional neurons. Adult neural stem cells are also found in the forebrain subventricular zone and in the olfactory bulb. In vitro, RA can increase neurogenesis by enhancing the proliferation and differentiation of adult forebrain neuroblasts, and in vivo it may regulate the proliferation of slowly dividing astrocytes in the subventricular zone (Haskell and LaMantia, 2005). Further characterisation of these functions might have important implications for the therapy or prevention of neurodegenerative diseases.

affected in the developing hindbrain. Other possible effectors of the RA-deficiency phenotype include Fgf genes, mainly $F g f 8$ and $F g f 3$, the expression of which was severely reduced in Raldh2 mutants. Neither the molecular nor the phenotypic studies provided clear evidence for an RA concentration gradient acting in the branchial region. They indicated, however, that the retinoid signal acts non-cell-autonomously: by analogy with the hindbrain model, it can be defined both as a 'vertical' signal travelling from mesenchyme to pharyngeal endoderm and as a 'planar' signal diffusing along the branchial region up to the level of the $3 \mathrm{rd}$ arch. Another parallel with the hindbrain is that RA action may be restricted by the activity of CYP26s, all of which are expressed in specific branchial/cervical cell populations (Table 1).

\section{RA signalling during lung development}

Region-specific retinoid signalling has other important functions in

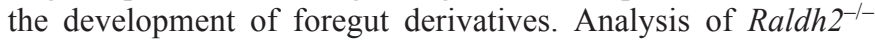
mutants and experiments performed on embryonic explants demonstrated that a lack of RA/RAR activity prevents induction and growth of the primary lung buds (Desai et al., 2006; Wang et al., 2006). The underlying molecular events include a lack of FgflO induction in the lung field (the region where primary lung buds are induced) caused by upregulation of TGF $\beta$ signalling, which has an inhibitory effect on FgflO expression (Chen et al., 2007; Chen et al., 2010).

\section{RA signalling and pancreas development}

It was demonstrated in zebrafish (see Alexa et al., 2009), Xenopus (Chen et al., 2004) and mouse (Martin et al., 2005; Molotkov et al., 2005) that RA is also required for pancreas development. Here, RA (produced mesodermally by RALDH2) acts by diffusing towards the endoderm, where most of the molecular abnormalities are observed under RA deficiency. The pancreas derives from two endodermal primordia known as the ventral and dorsal buds, and lack of RA specifically affects induction and growth of the dorsal pancreatic bud. One important role of RA is to downregulate $\mathrm{SHH}$ signalling, which has an inhibitory effect on pancreas induction. RA may also act at later steps of specification of pancreatic endocrine cell lineages (Martin et al., 2005; Ostrom et al., 2008). Recent work indicates that RA may act more globally to coordinate the position of endoderm-derived organs along the foregut and midgut A-P axis (Bayha et al., 2009), and that CYP26 enzymes may restrict the extent of RA signalling and set up the limit of the pancreatic field (Kinkel et al., 2009).

\section{RA and limb development}

Many early studies have investigated the role of RA in embryonic limb bud patterning, triggered by reports of its ability to induce mirror-image digit duplications when applied locally in chick wing buds (Tickle et al., 1982) and of the measurement of differential endogenous concentrations along the limb A-P axis (Thaller and Eichele, 1987). Abnormalities in limb skeletal patterning were first reported for $\mathrm{Rara}^{-/}$; $\mathrm{Rarg}^{-/-}$compound mutant mice (Lohnes et al., 1994), and it was later found that mutants for RA-synthesizing enzymes have hypoplastic or absent forelimb buds $\left(R d h 10^{-/}\right.$or

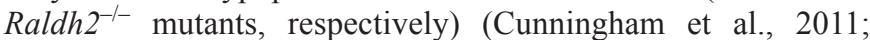
Niederreither et al., 1999; Sandell et al., 2007). A detailed study of compound Raldh mutants showed, however, that RA is not necessary for hindlimb development (Zhao et al., 2009). It was found that RA deficiency affects the expression of several regulators of forelimb bud growth and patterning, including $\mathrm{Fgft} / 8$ and Shh (Mic et al., 2004b; Niederreither et al., 2002). A subsequent study concluded that these effects are indirect, with RA acting outside of the limb bud and perhaps even before its induction: here, an RA-dependent inhibition of FGF8 signalling in the body axis near the forelimb field would create a permissive environment allowing limb bud induction (Zhao et al., 2009). Eventually, limb bud cells need to develop in an RA-protected environment, mainly through the sustained action of CYP26B1 (Probst et al., 2011; Yashiro et al., 2004). Interestingly, such a function might have arisen prior to tetrapod limb specialisation. Indeed, RA signalling is also required for the development of zebrafish pectoral fin buds, acting from gastrulation to early somite stages as a permissive signal for the proper induction and growth of the fin bud (Gibert et al., 2006; Grandel and Brand, 2011).

\section{RA function during somitogenesis and neural tube differentiation}

Many in-depth studies have investigated the functions of RA during elongation of the embryonic body axis, where it controls several events relating to mesodermal segmentation and neurogenesis in the caudal neural tube (the future spinal cord). Somites are segmented epithelial structures that are formed sequentially along the left and right paraxial mesoderm. They are the precursors of various tissues: their dorsal portion, the dermomyotome, will differentiate into muscle and dermis, whereas their ventral part, the sclerotome, gives rise to skeletal elements (vertebral column and ribs). Somite formation is a rhythmic process that relies on a 'clock and wavefront' mechanism, in which a molecular oscillator driven by Wnt and Notch signalling generates cyclic waves of gene expression that progress rostrally along the PSM (reviewed by Gibb et al., 2010). This oscillator interacts with a system of 
signalling gradients to create a maturation or 'determination' front, which is displaced posteriorly as the embryonic axis elongates. PSM cells become competent to respond to the oscillations when they become located anterior to the determination front, initiating the programme of somite formation. Recent findings suggest that the mechanism controlling the position of this front involves two dynamic, antagonizing gradients: a caudal-to-rostral Wnt/FGF gradient and an opposing RA gradient (Fig. 6) (Diez del Corral et al., 2003) (reviewed by Aulehla and Pourquie, 2010; Pourquie, 2011). As demonstrated by reporter transgenes, at gastrulation stages RA activity becomes progressively excluded from the posteriormost mesoderm, correlating with the onset of Cyp26al expression in this region (Ribes et al., 2009; Sirbu and Duester, 2006). At later stages during axial elongation, Raldh2 is specifically expressed in the newly formed somites and anteriormost PSM. Analysis of VAD quail embryos and Raldh2 $2^{-/-}$ mouse mutants revealed that lack of RA signalling leads to an anterior expansion of the $F g f 8$ domain along the PSM and to the formation of smaller somites (Diez del Corral et al., 2003; Vermot et al., 2005). RA has the ability to repress posterior ectodermal expression of $F g f 8$ for a short period of time when the somitogenesis molecular clock initiates (Sirbu and Duester, 2006).

Another important role of RA is to control the bilateral symmetry of the left and right somitic columns. Raldh $2^{-/-}$mouse embryos often exhibit fewer somites on one (usually the right) side (Vermot et al., 2005). This asymmetry in somite formation is caused by the desynchronisation of the molecular waves of expression along the left and right PSM. Similar findings were obtained by experimentally interfering with RA signalling in chick (Vermot and Pourquie, 2005) and zebrafish (Kawakami et al., 2005) embryos. Recently, it was shown that a mutation in mouse Rere (which encodes a chromatin-remodelling protein also known as atrophin) leads to an asymmetry in somite formation similar to that observed in Raldh2 ${ }^{-l-}$ embryos (Vilhais-Neto et al., 2010). These authors showed that RERE positively regulates RA signalling by forming a complex with the nuclear receptor NR2F2 (COUP-TFII), p300 (EP300) and RARs, thereby promoting transcriptional activation of target genes. Interestingly, $N r 2 f 2$ was found to be asymmetrically expressed in the right PSM, in a domain coinciding with asymmetrical RA signalling as detected by a reporter transgene. This led to a revised model in which transient asymmetrical RA signalling acts to 'buffer' asymmetrically expressed molecules that act as determinants of the embryonic leftright axis, shielding the PSM from the desynchronizing action of these signals (Vilhais-Neto et al., 2010).

Intimately linked to mesodermal differentiation during body elongation is the process of cell fate determination within the developing spinal cord. RA acts by diffusing from paraxial/somitic mesoderm to the adjacent neural plate to control several molecular events necessary for the specification of neuronal cell types in the prospective spinal cord (Diez del Corral et al., 2003; Molotkova et al., 2005; Novitch et al., 2003; Wilson et al., 2004). Crucial to this process is the previously described functional antagonism between RA and FGF signalling, the latter acting to maintain a proliferative 'stem' zone in the caudalmost neural plate (Fig. 6). High FGF levels have an inhibitory effect on Raldh2 expression, and the presence of CYP26A1 in the caudal stem zone further prevents any inappropriate RA signalling. Once the FGF signal is attenuated along the PSM, RA will trigger the onset of spinal cord differentiation and promotes the induction of genes involved in the determination of ventral neuronal cell types. Importantly, canonical Wnt signalling mediates the transition from FGF to RA signalling

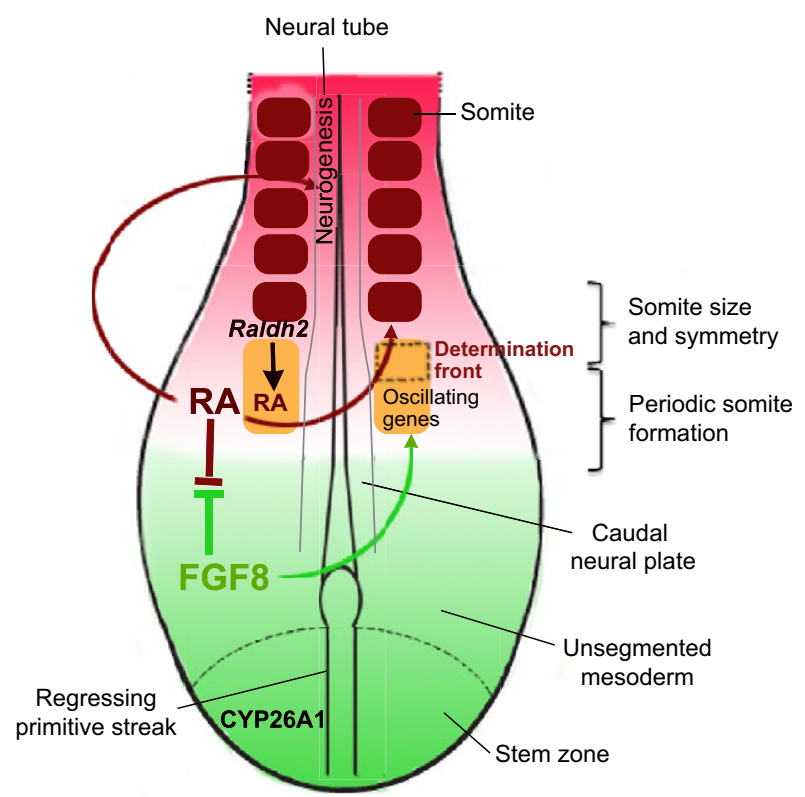

Fig. 6. Summary of RA functions during somitogenesis and neural tube differentiation. The posterior region of an embryo at early somite stages. The regions subject to the influence of RA (somites, rostral presomitic mesoderm and adjacent neural tube) or FGF signals (posterior stem zone, newly formed neural plate and mesoderm) appear in red and green, respectively, and the mutual antagonism between these signals is highlighted (bars). The location of the next somite to be formed, which includes a 'determination front', is shown in orange. The scheme has been assimilated from, and incorporates data further discussed in, the literature (Diez del Corral et al., 2003; Diez del Corral et al., 2004; Pourquie, 2011; Ribes et al., 2009; Wilson et al., 2009).

during axis elongation (Olivera-Martinez and Storey, 2007). These events have been reviewed in detail elsewhere (Diez del Corral and Storey, 2004; Wilson et al., 2009).

\section{Conclusions}

Although there has been tremendous progress in characterising the numerous developmental events regulated by the retinoid pathway, many gaps remain with respect to the underlying mechanisms of RA-mediated patterning. It is unclear, in particular, whether there is a unifying mechanism that explains the effects of retinoids on cell proliferation, survival and/or differentiation, or whether there might be different outcomes in various developing systems. Interpretation of experimental data are complicated by the fact that exposure to RA (in cultured cells, whole embryos or explants) may have different, sometimes opposite, effects depending on the concentration, stage or duration of exposure. Strategies that interfere with endogenous retinoid signalling (e.g. through genetic loss-of-function, morpholinos) appear more reliable than approaches using exogenous retinoids, including $\mathrm{RAR} / \mathrm{RXR}$ antagonists that may lead to the forced repression of target gene loci. The issue of whether RA functions as a true morphogen is still under debate and, surprisingly, it seems that this question has been less satisfactorily addressed for RA than for other candidate morphogens. For instance, there have been few attempts to assess how this signal is transmitted along embryonic cell populations using real-time live imaging. Progress on this issue will require the generation of more suitable reporter systems using short-lived fluorescent proteins. 
Information on the molecular targets of RA signalling is also fragmentary. Recent studies led to novel insights into the interplay between retinoid and other signalling pathways (such as FGF, Hedgehog, TGF $\beta$ ) in several developing systems. However, a better knowledge of the immediate early RA target genes is necessary to clarify whether there are common regulatory networks, rather than specific gene targets, for each system. Transcriptomic analyses have begun to yield valuable information, both in cell lines and embryonic tissues (e.g. Chen et al., 2007). Studies at the chromatin level have thus far been hindered by the lack of high-grade RAR antibodies, and so far are only available for cultured cell lines (Delacroix et al., 2010; Mahony et al., 2011). The next challenges will be to decipher the molecular events that are regulated in vivo by RA signalling, and to determine how these events correlate with effects on cell growth, determination and/or differentiation in specific progenitor populations. This research will remain of paramount importance as retinoids will not only continue to be used as 'conventional' drugs, but are also promising compounds for modulating cell behaviour in stem cell-based therapy.

\section{Acknowledgements}

We thank Prof. P. Chambon and Drs W. Krezel and M. Paschaki for critical reading of the manuscript and members of our laboratory for constructive comments. We acknowledge that many relevant studies could not be discussed or quoted owing to length restrictions.

\section{Funding}

The authors' work is funded by institutional funds from the CNRS, INSERM and Université de Strasbourg, and by grants from l'Agence Nationale de la Recherche (ANR) and Fondation pour la Recherche Médicale.

Competing interests statement

The authors declare no competing financial interests.

\section{References}

Abu-Abed, S., Dollé, P., Metzger, D., Beckett, B., Chambon, P. and Petkovich, M. (2001). The retinoic acid-metabolizing enzyme, CYP26A1, is essential for normal hindbrain patterning, vertebral identity, and development of posterior structures. Genes Dev. 15, 226-240.

Abu-Abed, S., MacLean, G., Fraulob, V., Chambon, P., Petkovich, M. and Dollé, P. (2002). Differential expression of the retinoic acid-metabolizing enzymes CYP26A1 and CYP26B1 during murine organogenesis. Mech. Dev. $110,173-177$

Abu-Abed, S., Dollé, P., Metzger, D., Wood, C., MacLean, G., Chambon, P. and Petkovich, M. (2003). Developing with lethal RA levels: genetic ablation of Rarg can restore the viability of mice lacking Cyp26a1. Development 130, 14491459.

Alexa, K., Choe, S. K., Hirsch, N., Etheridge, L., Laver, E. and Sagerstrom, C. G. (2009). Maternal and zygotic aldh1a2 activity is required for pancreas development in zebrafish. PLOS ONE 4, e8261.

Ang, H. L., Deltour, L., Hayamizu, T. F., Zgombic-Knight, M. and Duester, G. (1996). Retinoic acid synthesis in mouse embryos during gastrulation and craniofacial development linked to class IV alcohol dehydrogenase gene expression. J. Biol. Chem. 271, 9526-9534.

Aulehla, A. and Pourquie, O. (2010). Signaling gradients during paraxial mesoderm development. Cold Spring Harb. Perspect. Biol. 2, a000869.

Avantaggiato, V., Acampora, D., Tuorto, F. and Simeone, A. (1996). Retinoic acid induces stage-specific repatterning of the rostral central nervous system. Dev. Biol. 175, 347-357.

Balmer, J. E. and Blomhoff, R. (2002). Gene expression regulation by retinoic acid. J. Lipid Res. 43, 1773-1808.

Balmer, J. E. and Blomhoff, R. (2005). A robust characterization of retinoic acid response elements based on a comparison of sites in three species. J. Steroid Biochem. Mol. Biol. 96, 347-354.

Batourina, E., Gim, S., Bello, N., Shy, M., Clagett-Dame, M., Srinivas, S., Costantini, F. and Mendelsohn, C. (2001). Vitamin A controls epithelial/mesenchymal interactions through Ret expression. Nat. Genet. 27, 7478.

Bayha, E., Jorgensen, M. C., Serup, P. and Grapin-Botton, A. (2009). Retinoic acid signaling organizes endodermal organ specification along the entire anteroposterior axis. PLOS ONE 4, e5845.
Begemann, G., Schilling, T. F., Rauch, G. J., Geisler, R. and Ingham, P. W. (2001). The zebrafish neckless mutation reveals a requirement for raldh2 in mesodermal signals that pattern the hindbrain. Development 128, 3081-3094.

Bibel, M., Richter, J., Schrenk, K., Tucker, K. L., Staiger, V., Korte, M., Goetz, M. and Barde, Y. A. (2004). Differentiation of mouse embryonic stem cells into a defined neuronal lineage. Nat. Neurosci. 7, 1003-1009.

Blentic, A., Gale, E. and Maden, M. (2003). Retinoic acid signalling centres in the avian embryo identified by sites of expression of synthesising and catabolising enzymes. Dev. Dyn. 227, 114-127.

Bonnet, E., Touyarot, K., Alfos, S., Pallet, V., Higueret, P. and Abrous, D. N. (2008). Retinoic acid restores adult hippocampal neurogenesis and reverses spatial memory deficit in vitamin A deprived rats. PLOS ONE 3, e3487.

Bowles, J., Knight, D., Smith, C., Wilhelm, D., Richman, J., Mamiya, S., Yashiro, K., Chawengsaksophak, K., Wilson, M. J., Rossant, J. et al. (2006). Retinoid signaling determines germ cell fate in mice. Science 312, 596-600.

Cammas, L., Romand, R., Fraulob, V., Mura, C. and Dollé, P. (2007). Expression of the murine retinol dehydrogenase 10 (Rdh10) gene correlates with many sites of retinoid signalling during embryogenesis and organ differentiation. Dev. Dyn. 236, 2899-2908

Chapellier, B., Mark, M., Messaddeq, N., Calleja, C., Warot, X., Brocard, J. Gerard, C., Li, M., Metzger, D., Ghyselinck, N. B. et al. (2002). Physiological and retinoid-induced proliferations of epidermis basal keratinocytes are differently controlled. EMBO J. 21, 3402-3413.

Chatzi, C., Brade, T. and Duester, G. (2011). Retinoic acid functions as a key GABAergic differentiation signal in the basal ganglia. PLoS Biol. 9, e1000609.

Chawla, A., Repa, J. J., Evans, R. M. and Mangelsdorf, D. J. (2001). Nuclear receptors and lipid physiology: opening the X-files. Science 294, 1866-1870.

Chen, F., Desai, T. J., Qian, J., Niederreither, K., Lu, J. and Cardoso, W. V. (2007). Inhibition of Tgf beta signaling by endogenous retinoic acid is essential for primary lung bud induction. Development 134, 2969-2979.

Chen, F., Cao, Y., Qian, J., Shao, F., Niederreither, K. and Cardoso, W. V. (2010). A retinoic acid-dependent network in the foregut controls formation of the mouse lung primordium. J. Clin. Invest. 120, 2040-2048.

Chen, Y., Pan, F. C., Brandes, N., Afelik, S., Solter, M. and Pieler, T. (2004). Retinoic acid signaling is essential for pancreas development and promotes endocrine at the expense of exocrine cell differentiation in Xenopus. Dev. Biol. $271,144-160$

Chithalen, J. V., Luu, L., Petkovich, M. and Jones, G. (2002). HPLC-MS/MS analysis of the products generated from all-trans-retinoic acid using recombinant human CYP26A. J. Lipid Res. 43, 1133-1142.

Cunningham, T. J., Chatzi, C., Sandell, L. L., Trainor, P. A. and Duester, G. (2011). Rdh10 mutants deficient in limb field retinoic acid signaling exhibit normal limb patterning but display interdigital webbing. Dev. Dyn. 240, 11421150

D’Ambrosio, D. N., Clugston, R. D. and Blaner, W. S. (2011). Vitamin A metabolism: an update. Nutrients 3, 63-103.

Delacroix, L., Moutier, E., Altobelli, G., Legras, S., Poch, O., Choukrallah, M. A., Bertin, I., Jost, B. and Davidson, I. (2010). Cell-specific interaction of retinoic acid receptors with target genes in mouse embryonic fibroblasts and embryonic stem cells. Mol. Cell. Biol. 30, 231-244.

Deltour, L., Foglio, M. H. and Duester, G. (1999a). Impaired retinol utilization in Adh4 alcohol dehydrogenase mutant mice. Dev. Genet. 25, 1-10.

Deltour, L., Foglio, M. H. and Duester, G. (1999b). Metabolic deficiencies in alcohol dehydrogenase Adh1, Adh3, and Adh4 null mutant mice. Overlapping roles of Adh1 and Adh4 in ethanol clearance and metabolism of retinol to retinoic acid. J. Biol. Chem. 274, 16796-16801.

Desai, T. J., Chen, F., Lu, J., Qian, J., Niederreither, K., Dollé, P., Chambon, P. and Cardoso, W. V. (2006). Distinct roles for retinoic acid receptors alpha and beta in early lung morphogenesis. Dev. Biol. 291, 12-24.

Diez del Corral, R. and Storey, K. G. (2004). Opposing FGF and retinoid pathways: a signalling switch that controls differentiation and patterning onset in the extending vertebrate body axis. BioEssays 26, 857-869.

Diez del Corral, R., Olivera-Martinez, I., Goriely, A., Gale, E., Maden, M. and Storey, K. (2003). Opposing FGF and retinoid pathways control ventral neural pattern, neuronal differentiation, and segmentation during body axis extension. Neuron 40, 65-79.

Dollé, P. (2009). Developmental expression of retinoic acid receptors (RARs). Nucl. Recept. Signal. 7, e006.

Dollé, P., Ruberte, E., Kastner, P., Petkovich, M., Stoner, C. M., Gudas, L. J. and Chambon, P. (1989). Differential expression of genes encoding alpha, beta and gamma retinoic acid receptors and CRABP in the developing limbs of the mouse. Nature 342, 702-705.

Dollé, P., Fraulob, V., Kastner, P. and Chambon, P. (1994). Developmental expression of murine retinoid X receptor (RXR) genes. Mech. Dev. 45, 91-104.

Driessen, C. A., Winkens, H. J., Hoffmann, K., Kuhlmann, L. D., Janssen, B. P., Van Vugt, A. H., Van Hooser, J. P., Wieringa, B. E., Deutman, A. F., Palczewski, K. et al. (2000). Disruption of the 11-cis-retinol dehydrogenase gene leads to accumulation of cis-retinols and cis-retinyl esters. Mol. Cell. Biol. 20, 4275-4287. 
Duester, G. (2008). Retinoic acid synthesis and signaling during early organogenesis. Cell 134, 921-931.

Dupé, V. and Lumsden, A. (2001). Hindbrain patterning involves graded responses to retinoic acid signalling. Development 128, 2199-2208.

Dupé, V., Ghyselinck, N. B., Wendling, O., Chambon, P. and Mark, M. (1999) Key roles of retinoic acid receptors alpha and beta in the patterning of the caudal hindbrain, pharyngeal arches and otocyst in the mouse. Development 126, 5051-5059.

Dupé, V., Matt, N., Garnier, J. M., Chambon, P., Mark, M. and Ghyselinck, N. B. (2003). A newborn lethal defect due to inactivation of retinaldehyde dehydrogenase type 3 is prevented by maternal retinoic acid treatment. Proc. Natl. Acad. Sci. USA 100, 14036-14041.

Durston, A. J., Timmermans, J. P., Hage, W. J., Hendriks, H. F., de Vries, N. J., Heideveld, M. and Nieuwkoop, P. D. (1989). Retinoic acid causes an anteroposterior transformation in the developing central nervous system. Nature 340, 140-144

Fan, X., Molotkov, A., Manabe, S., Donmoyer, C. M., Deltour, L., Foglio, M. H., Cuenca, A. E., Blaner, W. S., Lipton, S. A. and Duester, G. (2003). Targeted disruption of Aldh1a1 (Raldh1) provides evidence for a complex mechanism of retinoic acid synthesis in the developing retina. Mol. Cell. Biol. 23, 4637-4648.

Fujii, H., Sato, T., Kaneko, S., Gotoh, O., Fujii-Kuriyama, Y., Osawa, K., Kato, S. and Hamada, H. (1997). Metabolic inactivation of retinoic acid by a novel P450 differentially expressed in developing mouse embryos. EMBO J. 16, 41634173

Gale, E., Zile, M. and Maden, M. (1999). Hindbrain respecification in the retinoid-deficient quail. Mech. Dev. 89, 43-54

Ghyselinck, N. B., Dupé, V., Dierich, A., Messaddeq, N., Garnier, J. M. Rochette-Egly, C., Chambon, P. and Mark, M. (1997). Role of the retinoic acid receptor beta (RARbeta) during mouse development. Int. J. Dev. Biol. 41, 425-447.

Gibb, S., Maroto, M. and Dale, J. K. (2010). The segmentation clock mechanism moves up a notch. Trends Cell Biol. 20, 593-600.

Gibert, Y., Gajewski, A., Meyer, A. and Begemann, G. (2006). Induction and prepatterning of the zebrafish pectoral fin bud requires axial retinoic acid signaling. Development 133, 2649-2659.

Grandel, H. and Brand, M. (2011). Zebrafish limb development is triggered by a retinoic acid signal during gastrulation. Dev. Dyn. 240, 1116-1126.

Grandel, H., Lun, K., Rauch, G. J., Rhinn, M., Piotrowski, T., Houart, C. Sordino, P., Kuchler, A. M., Schulte-Merker, S., Geisler, R. et al. (2002). Retinoic acid signalling in the zebrafish embryo is necessary during presegmentation stages to pattern the anterior-posterior axis of the CNS and to induce a pectoral fin bud. Development 129, 2851-2865.

Gruber, P. J., Kubalak, S. W., Pexieder, T., Sucov, H. M., Evans, R. M. and Chien, K. R. (1996). RXR alpha deficiency confers genetic susceptibility for aortic sac, conotruncal, atrioventricular cushion, and ventricular muscle defects in mice. J. Clin. Invest. 98, 1332-1343.

Grun, F., Hirose, Y., Kawauchi, S., Ogura, T. and Umesono, K. (2000) Aldehyde dehydrogenase 6 , a cytosolic retinaldehyde dehydrogenase prominently expressed in sensory neuroepithelia during development. J. Biol. Chem. 275, 41210-41218

Guris, D. L., Duester, G., Papaioannou, V. E. and Imamoto, A. (2006). Dosedependent interaction of Tbx1 and Crkl and locally aberrant RA signaling in a model of del22q11 syndrome. Dev. Cell 10, 81-92.

Halilagic, A., Zile, M. H. and Studer, M. (2003). A novel role for retinoids in patterning the avian forebrain during presomite stages. Development $\mathbf{1 3 0}$ 2039-2050.

Haselbeck, R. J., Hoffmann, I. and Duester, G. (1999). Distinct functions for Aldh1 and Raldh2 in the control of ligand production for embryonic retinoid signaling pathways. Dev. Genet. 25, 353-364.

Haskell, G. T. and LaMantia, A. S. (2005). Retinoic acid signaling identifies a distinct precursor population in the developing and adult forebrain. J. Neurosci. 25, 7636-7647.

Hernandez, R. E., Putzke, A. P., Myers, J. P., Margaretha, L. and Moens, C. B. (2007). Cyp26 enzymes generate the retinoic acid response pattern necessary for hindbrain development. Development 134, 177-187

Hoover, F. and Glover, J. C. (1998). Regional pattern of retinoid X receptor-alpha gene expression in the central nervous system of the chicken embryo and its upregulation by exposure to 9 -cis retinoic acid. J. Comp. Neurol. 398, 575-586.

Kastner, P., Grondona, J. M., Mark, M., Gansmuller, A., LeMeur, M., Decimo, D., Vonesch, J. L., Dollé, P. and Chambon, P. (1994). Genetic analysis of RXR alpha developmental function: convergence of RXR and RAR signaling pathways in heart and eye morphogenesis. Cell 78, 987-1003.

Kastner, P., Mark, M., Leid, M., Gansmuller, A., Chin, W., Grondona, J. M., Decimo, D., Krezel, W., Dierich, A. and Chambon, P. (1996). Abnormal spermatogenesis in RXR beta mutant mice. Genes Dev. 10, 80-92.

Kawaguchi, R., Yu, J., Honda, J., Hu, J., Whitelegge, J., Ping, P., Wiita, P., Bok, D. and Sun, H. (2007). A membrane receptor for retinol binding protein mediates cellular uptake of vitamin A. Science $\mathbf{3 1 5}, \mathbf{8 2 0 - 8 2 5}$
Kawakami, Y., Raya, A., Raya, R. M., Rodriguez-Esteban, C. and Belmonte, J. C. (2005). Retinoic acid signalling links left-right asymmetric patterning and bilaterally symmetric somitogenesis in the zebrafish embryo. Nature 435, 165 171

Kiecker, C. and Lumsden, A. (2005). Compartments and their boundaries in vertebrate brain development. Nat. Rev. Neurosci. 6, 553-564.

Kinkel, M. D., Sefton, E. M., Kikuchi, Y., Mizoguchi, T., Ward, A. B. and Prince, V. E. (2009). Cyp26 enzymes function in endoderm to regulate pancreatic field size. Proc. Natl. Acad. Sci. USA 106, 7864-7869.

Krezel, W., Ghyselinck, N., Samad, T. A., Dupé, V., Kastner, P., Borrelli, E. and Chambon, P. (1998). Impaired locomotion and dopamine signaling in retinoid receptor mutant mice. Science 279, 863-867.

Krzyzosiak, A., Szyszka-Niagolov, M., Wietrzych, M., Gobaille, S., Muramatsu, S. and Krezel, W. (2010). Retinoid x receptor gamma control of affective behaviors involves dopaminergic signaling in mice. Neuron 66, 908920

Lampert, J. M., Holzschuh, J., Hessel, S., Driever, W., Vogt, K. and von Lintig, J. (2003). Provitamin A conversion to retinal via the beta, beta-carotene-15, 15'oxygenase (bcox) is essential for pattern formation and differentiation during zebrafish embryogenesis. Development 130, 2173-2186.

Li, H., Wagner, E., McCaffery, P., Smith, D., Andreadis, A. and Drager, U. C. (2000). A retinoic acid synthesizing enzyme in ventral retina and telencephalon of the embryonic mouse. Mech. Dev. 95, 283-289.

Lohnes, D., Kastner, P., Dierich, A., Mark, M., LeMeur, M. and Chambon, P. (1993). Function of retinoic acid receptor gamma in the mouse. Cell 73, 643658

Lohnes, D., Mark, M., Mendelsohn, C., Dollé, P., Dierich, A., Gorry, P., Gansmuller, A. and Chambon, P. (1994). Function of the retinoic acid receptors (RARs) during development (I). Craniofacial and skeletal abnormalities in RAR double mutants. Development 120, 2723-2748.

Loudig, O., Maclean, G. A., Dore, N. L., Luu, L. and Petkovich, M. (2005). Transcriptional co-operativity between distant retinoic acid response elements in regulation of Cyp26A1 inducibility. Biochem. J. 392, 241-248.

Lufkin, T., Lohnes, D., Mark, M., Dierich, A., Gorry, P., Gaub, M. P., LeMeur, M. and Chambon, P. (1993). High postnatal lethality and testis degeneration in retinoic acid receptor alpha mutant mice. Proc. Natl. Acad. Sci. USA 90, 72257229.

Luijten, M., van Beelen, V. A., Verhoef, A., Renkens, M. F., van Herwijnen, M. H., Westerman, A., van Schooten, F. J., Pennings, J. L. and Piersma, A. H. (2010). Transcriptomics analysis of retinoic acid embryotoxicity in rat postimplantation whole embryo culture. Reprod. Toxicol. 30, 333-340.

MacLean, G., Abu-Abed, S., Dollé, P., Tahayato, A., Chambon, P. and Petkovich, M. (2001). Cloning of a novel retinoic-acid metabolizing cytochrome P450, Cyp26B1, and comparative expression analysis with Cyp26A1 during early murine development. Mech. Dev. 107, 195-201.

MacLean, G., Li, H., Metzger, D., Chambon, P. and Petkovich, M. (2007) Apoptotic extinction of germ cells in testes of Cyp26b1 knockout mice. Endocrinology 148, 4560-4567.

MacLean, G., Dollé, P. and Petkovich, M. (2009). Genetic disruption of CYP26B1 severely affects development of neural crest derived head structures, but does not compromise hindbrain patterning. Dev. Dyn. 238, 732-745.

Mahony, S., Mazzoni, E. O., McCuine, S., Young, R. A., Wichterle, H. and Gifford, D. K. (2011). Ligand-dependent dynamics of retinoic acid receptor binding during early neurogenesis. Genome Biol. 12, R2

Mark, M., Ghyselinck, N. B. and Chambon, P. (2009). Function of retinoic acid receptors during embryonic development. Nucl. Recept. Signal. 7, e002.

Marklund, M., Sjodal, M., Beehler, B. C., Jessell, T. M., Edlund, T. and Gunhaga, L. (2004). Retinoic acid signalling specifies intermediate character in the developing telencephalon. Development 131, 4323-4332.

Marshall, H., Morrison, A., Studer, M., Popperl, H. and Krumlauf, R. (1996). Retinoids and Hox genes. FASEB J. 10, 969-978.

Martin, M., Gallego-Llamas, J., Ribes, V., Kedinger, M., Niederreither, K., Chambon, P., Dollé, P. and Gradwohl, G. (2005). Dorsal pancreas agenesis in retinoic acid-deficient Raldh2 mutant mice. Dev. Biol. 284, 399-411.

Matt, N., Dupé, V., Garnier, J. M., Dennefeld, C., Chambon, P., Mark, M. and Ghyselinck, N. B. (2005). Retinoic acid-dependent eye morphogenesis is orchestrated by neural crest cells. Development 132, 4789-4800.

Maves, L. and Kimmel, C. B. (2005). Dynamic and sequential patterning of the zebrafish posterior hindbrain by retinoic acid. Dev. Biol. 285, 593-605.

Maw, M. A., Kennedy, B., Knight, A., Bridges, R., Roth, K. E., Mani, E. J., Mukkadan, J. K., Nancarrow, D., Crabb, J. W. and Denton, M. J. (1997). Mutation of the gene encoding cellular retinaldehyde-binding protein in autosomal recessive retinitis pigmentosa. Nat. Genet. 17, 198-200.

Mendelsohn, C., Lohnes, D., Decimo, D., Lufkin, T., LeMeur, M., Chambon, P. and Mark, M. (1994). Function of the retinoic acid receptors (RARs) during development (II). Multiple abnormalities at various stages of organogenesis in RAR double mutants. Development 120, 2749-2771.

Merki, E., Zamora, M., Raya, A., Kawakami, Y., Wang, J., Zhang, X., Burch, J., Kubalak, S. W., Kaliman, P., Belmonte, J. C. et al. (2005). Epicardial 
retinoid $X$ receptor alpha is required for myocardial growth and coronary artery formation. Proc. Natl. Acad. Sci. USA 102, 18455-18460.

Mic, F. A., Molotkov, A., Fan, X., Cuenca, A. E. and Duester, G. (2000). $\mathrm{RALDH} 3$, a retinaldehyde dehydrogenase that generates retinoic acid, is expressed in the ventral retina, otic vesicle and olfactory pit during mouse development. Mech. Dev. 97, 227-230

Mic, F. A., Haselbeck, R. J., Cuenca, A. E. and Duester, G. (2002). Novel retinoic acid generating activities in the neural tube and heart identified by conditional rescue of Raldh2 null mutant mice. Development 129, 2271-2282.

Mic, F. A., Molotkov, A., Benbrook, D. M. and Duester, G. (2003). Retinoid activation of retinoic acid receptor but not retinoid $X$ receptor is sufficient to rescue lethal defect in retinoic acid synthesis. Proc. Natl. Acad. Sci. USA 100, 7135-7140

Mic, F. A., Molotkov, A., Molotkova, N. and Duester, G. (2004a). Raldh2 expression in optic vesicle generates a retinoic acid signal needed for invagination of retina during optic cup formation. Dev. Dyn. 231, 270-277.

Mic, F. A., Sirbu, I. O. and Duester, G. (2004b). Retinoic acid synthesis controlled by Raldh2 is required early for limb bud initiation and then later as a proximodistal signal during apical ectodermal ridge formation. J. Biol. Chem. 279, 26698-26706.

Molotkov, A., Fan, X., Deltour, L., Foglio, M. H., Martras, S., Farres, J., Pares, $\mathbf{X}$. and Duester, G. (2002a). Stimulation of retinoic acid production and growth by ubiquitously expressed alcohol dehydrogenase Adh3. Proc. Natl. Acad. Sci. USA 99, 5337-5342

Molotkov, A., Fan, X. and Duester, G. (2002b). Excessive vitamin A toxicity in mice genetically deficient in either alcohol dehydrogenase Adh1 or Adh3. Eur. J. Biochem. 269, 2607-2612

Molotkov, A., Molotkova, N. and Duester, G. (2005). Retinoic acid generated by Raldh2 in mesoderm is required for mouse dorsal endodermal pancreas development. Dev. Dyn. 232, 950-957.

Molotkov, A., Molotkova, N. and Duester, G. (2006). Retinoic acid guides eye morphogenetic movements via paracrine signaling but is unnecessary for retinal dorsoventral patterning. Development 133, 1901-1910.

Molotkova, N., Molotkov, A., Sirbu, I. O. and Duester, G. (2005). Requirement of mesodermal retinoic acid generated by Raldh2 for posterior neural transformation. Mech. Dev. 122, 145-155.

Molotkova, N., Molotkov, A. and Duester, G. (2007). Role of retinoic acid during forebrain development begins late when Raldh3 generates retinoic acid in the ventral subventricular zone. Dev. Biol. 303, 601-610.

Morriss, G. M. (1972). Morphogenesis of the malformations induced in rat embryos by maternal hypervitaminosis A. J. Anat. 113, 241-250.

Niederreither, K. and Dollé, P. (2008). Retinoic acid in development: towards an integrated view. Nat. Rev. Genet. 9, 541-553.

Niederreither, K., McCaffery, P., Drager, U. C., Chambon, P. and Dollé, P. (1997). Restricted expression and retinoic acid-induced downregulation of the retinaldehyde dehydrogenase type 2 (RALDH-2) gene during mouse development. Mech. Dev. 62, 67-78.

Niederreither, K., Subbarayan, V., Dollé, P. and Chambon, P. (1999). Embryonic retinoic acid synthesis is essential for early mouse post-implantation development. Nat. Genet. 21, 444-448.

Niederreither, K., Vermot, J., Schuhbaur, B., Chambon, P. and Dollé, P. (2000). Retinoic acid synthesis and hindbrain patterning in the mouse embryo. Development 127, 75-85.

Niederreither, K., Vermot, J., Messaddeq, N., Schuhbaur, B., Chambon, P. and Dollé, P. (2001). Embryonic retinoic acid synthesis is essential for heart morphogenesis in the mouse. Development 128, 1019-1031.

Niederreither, K., Vermot, J., Schuhbaur, B., Chambon, P. and Dollé, P. (2002). Embryonic retinoic acid synthesis is required for forelimb growth and anteroposterior patterning in the mouse. Development 129, 3563-3574.

Niederreither, K., Vermot, J., Le Roux, I., Schuhbaur, B., Chambon, P. and Dollé, $\mathbf{P}$. (2003). The regional pattern of retinoic acid synthesis by RALDH2 is essential for the development of posterior pharyngeal arches and the enteric nervous system. Development 130, 2525-2534

Novitch, B. G., Wichterle, H., Jessell, T. M. and Sockanathan, S. (2003). A requirement for retinoic acid-mediated transcriptional activation in ventral neural patterning and motor neuron specification. Neuron 40, 81-95.

Olivera-Martinez, I. and Storey, K. G. (2007). Wnt signals provide a timing mechanism for the FGF-retinoid differentiation switch during vertebrate body axis extension. Development 134, 2125-2135.

Ostrom, M., Loffler, K. A., Edfalk, S., Selander, L., Dahl, U., Ricordi, C., Jeon, J., Correa-Medina, M., Diez, J. and Edlund, H. (2008). Retinoic acid promotes the generation of pancreatic endocrine progenitor cells and their further differentiation into beta-cells. PLoS ONE 3, e2841.

Pares, X., Farres, J., Kedishvili, N. and Duester, G. (2008). Medium- and shortchain dehydrogenase/reductase gene and protein families: medium-chain and short-chain dehydrogenases/reductases in retinoid metabolism. Cell. Mol. Life Sci. 65, 3936-3949.

Parker, R. O. and Crouch, R. K. (2010). Retinol dehydrogenases (RDHs) in the visual cycle. Exp. Eye Res. 91, 788-792.
Pasutto, F., Sticht, H., Hammersen, G., Gillessen-Kaesbach, G., Fitzpatrick, D. R., Nurnberg, G., Brasch, F., Schirmer-Zimmermann, H., Tolmie, J. L., Chitayat, D. et al. (2007). Mutations in STRA6 cause a broad spectrum of malformations including anophthalmia, congenital heart defects, diaphragmatic hernia, alveolar capillary dysplasia, lung hypoplasia, and mental retardation. Am. J. Hum. Genet. 80, 550-560

Pennimpede, T., Cameron, D. A., MacLean, G. A., Li, H., Abu-Abed, S. and Petkovich, M. (2010). The role of CYP26 enzymes in defining appropriate retinoic acid exposure during embryogenesis. Birth Defects Res. A Clin. Mol. Teratol. 88, 883-894.

Pijnappel, W. W., Hendriks, H. F., Folkers, G. E., van den Brink, C. E., Dekker, E. J., Edelenbosch, C., van der Saag, P. T. and Durston, A. J. (1993). The retinoid ligand 4-oxo-retinoic acid is a highly active modulator of positional specification. Nature 366, 340-344

Plachta, N., Bibel, M., Tucker, K. L. and Barde, Y. A. (2004). Developmental potential of defined neural progenitors derived from mouse embryonic stem cells. Development 131, 5449-5456.

Pourquie, 0. (2011). Vertebrate segmentation: from cyclic gene networks to scoliosis. Cell 145, 650-663.

Probst, S., Kraemer, C., Demougin, P., Sheth, R., Martin, G. R., Shiratori, H., Hamada, H., Iber, D., Zeller, R. and Zuniga, A. (2011). SHH propagates distal limb bud development by enhancing CYP26B1-mediated retinoic acid clearance via AER-FGF signalling. Development 138, 1913-1923.

Quadro, L., Hamberger, L., Gottesman, M. E., Wang, F., Colantuoni, V., Blaner, W. S. and Mendelsohn, C. L. (2005). Pathways of vitamin A delivery to the embryo: insights from a new tunable model of embryonic vitamin A deficiency. Endocrinology 146, 4479-4490.

Rajaii, F., Bitzer, Z. T., Xu, Q. and Sockanathan, S. (2008). Expression of the dominant negative retinoid receptor, RAR403, alters telencephalic progenitor proliferation, survival, and cell fate specification. Dev. Biol. 316, 371-382

Reijntjes, S., Gale, E. and Maden, M. (2003). Expression of the retinoic acid catabolising enzyme CYP26B1 in the chick embryo and its regulation by retinoic acid. Gene Expr. Patterns 3, 621-627

Reijntjes, S., Gale, E. and Maden, M. (2004). Generating gradients of retinoic acid in the chick embryo: Cyp26C 1 expression and a comparative analysis of the Cyp26 enzymes. Dev. Dyn. 230, 509-517

Reijntjes, S., Zile, M. H. and Maden, M. (2010). The expression of Stra6 and Rdh10 in the avian embryo and their contribution to the generation of retinoid signatures. Int. J. Dev. Biol. 54, 1267-1275.

Rhinn, M., Schuhbaur, B., Niederreither, K. and Dollé, P. (2011). Involvement of retinol dehydrogenase 10 in embryonic patterning and rescue of its loss of function by maternal retinaldehyde treatment. Proc. Natl. Acad. Sci. USA 108, 16687-16692.

Ribes, V., Wang, Z., Dollé, P. and Niederreither, K. (2006). Retinaldehyde dehydrogenase 2 (RALDH2)-mediated retinoic acid synthesis regulates early mouse embryonic forebrain development by controlling FGF and sonic hedgehog signaling. Development 133, 351-361.

Ribes, V., Otto, D. M., Dickmann, L., Schmidt, K., Schuhbaur, B., Henderson, C., Blomhoff, R., Wolf, C. R., Tickle, C. and Dollé, P. (2007). Rescue of cytochrome P450 oxidoreductase (Por) mouse mutants reveals functions in vasculogenesis, brain and limb patterning linked to retinoic acid homeostasis. Dev. Biol. 303, 66-81.

Ribes, V., Le Roux, I., Rhinn, M., Schuhbaur, B. and Dollé, P. (2009). Early mouse caudal development relies on crosstalk between retinoic acid, Shh and Fgf signalling pathways. Development 136, 665-676.

Rijli, F. M., Gavalas, A. and Chambon, P. (1998). Segmentation and specification in the branchial region of the head: the role of the Hox selector genes. Int. J. Dev. Biol. 42, 393-401.

Rochette-Egly, C. and Germain, P. (2009). Dynamic and combinatorial control of gene expression by nuclear retinoic acid receptors (RARs). Nucl. Recept. Signal. 7, e005

Romand, R., Kondo, T., Fraulob, V., Petkovich, M., Dollé, P. and Hashino, E. (2006). Dynamic expression of retinoic acid-synthesizing and -metabolizing enzymes in the developing mouse inner ear. J. Comp. Neurol. 496, 643-654.

Romand, R., Kondo, T., Cammas, L., Hashino, E. and Dollé, P. (2008). Dynamic expression of the retinoic acid-synthesizing enzyme retinol dehydrogenase 10 (rdh10) in the developing mouse brain and sensory organs. J. Comp. Neurol. 508, 879-892.

Rowe, A. and Brickell, P. M. (1995). Expression of the chicken retinoid X receptor-gamma gene in migrating cranial neural crest cells. Anat. Embryol. (Berl.) 192, 1-8.

Ruberte, E., Dollé, P., Krust, A., Zelent, A., Morriss-Kay, G. and Chambon, P. (1990). Specific spatial and temporal distribution of retinoic acid receptor gamma transcripts during mouse embryogenesis. Development 108, 213-222.

Ruberte, E., Dollé, P., Chambon, P. and Morriss-Kay, G. (1991). Retinoic acid receptors and cellular retinoid binding proteins. II. Their differential pattern of transcription during early morphogenesis in mouse embryos. Development 111, 45-60.

Ruberte, E., Friederich, V., Chambon, P. and Morriss-Kay, G. (1993). Retinoic acid receptors and cellular retinoid binding proteins. III. Their differential 
transcript distribution during mouse nervous system development. Development 118, 267-282.

Ryckebusch, L., Bertrand, N., Mesbah, K., Bajolle, F., Niederreither, K., Kelly, R. G. and Zaffran, S. (2010). Decreased levels of embryonic retinoic acid synthesis accelerate recovery from arterial growth delay in a mouse model of DiGeorge syndrome. Circ. Res. 106, 686-694.

Sakai, Y., Meno, C., Fujii, H., Nishino, J., Shiratori, H., Saijoh, Y., Rossant, J. and Hamada, H. (2001). The retinoic acid-inactivating enzyme CYP26 is essential for establishing an uneven distribution of retinoic acid along the anterio-posterior axis within the mouse embryo. Genes Dev. 15, 213-225.

Sandell, L. L., Sanderson, B. W., Moiseyev, G., Johnson, T., Mushegian, A. Young, K., Rey, J. P., Ma, J. X., Staehling-Hampton, K. and Trainor, P. A (2007). RDH10 is essential for synthesis of embryonic retinoic acid and is required for limb, craniofacial, and organ development. Genes Dev. 21, 1113 1124.

Sapin, V., Dollé, P., Hindelang, C., Kastner, P. and Chambon, P. (1997). Defects of the chorioallantoic placenta in mouse RXRalpha null fetuses. Dev. Biol. 19, 2941.

Schneider, R. A., Hu, D., Rubenstein, J. L., Maden, M. and Helms, J. A. (2001). Local retinoid signaling coordinates forebrain and facial morphogenesis by maintaining FGF8 and SHH. Development 128, 2755-2767.

Schug, T. T., Berry, D. C., Shaw, N. S., Travis, S. N. and Noy, N. (2007) Opposing effects of retinoic acid on cell growth result from alternate activation of two different nuclear receptors. Cell 129, 723-733.

Siegenthaler, J. A., Ashique, A. M., Zarbalis, K., Patterson, K. P., Hecht, J. H., Kane, M. A., Folias, A. E., Choe, Y., May, S. R., Kume, T. et al. (2009). Retinoic acid from the meninges regulates cortical neuron generation. Cell 139 597-609.

Simoes-Costa, M. S., Azambuja, A. P. and Xavier-Neto, J. (2008). The search for non-chordate retinoic acid signaling: lessons from chordates. J. Exp. Zool. B Mol. Dev. Evol. 310, 54-72.

Sirbu, I. O. and Duester, G. (2006). Retinoic-acid signalling in node ectoderm and posterior neural plate directs left-right patterning of somitic mesoderm. Nat. Cell Biol. 8, 271-277.

Sirbu, I. O., Gresh, L., Barra, J. and Duester, G. (2005). Shifting boundaries of retinoic acid activity control hindbrain segmental gene expression. Development 132, 2611-2622.

Smith, D., Wagner, E., Koul, O., McCaffery, P. and Drager, U. C. (2001). Retinoic acid synthesis for the developing telencephalon. Cereb. Cortex 11, 894-905.

Smith, S. M. and Eichele, G. (1991). Temporal and regional differences in the expression pattern of distinct retinoic acid receptor-beta transcripts in the chick embryo. Development 111, 245-252

Strate, I., Min, T. H., Iliev, D. and Pera, E. M. (2009). Retinol dehydrogenase 10 is a feedback regulator of retinoic acid signalling during axis formation and patterning of the central nervous system. Development 136, 461-472.

Sucov, H. M., Dyson, E., Gumeringer, C. L., Price, J., Chien, K. R. and Evans, R. M. (1994). RXR alpha mutant mice establish a genetic basis for vitamin A signaling in heart morphogenesis. Genes Dev. 8, 1007-1018.

Suzuki, R., Shintani, T., Sakuta, H., Kato, A., Ohkawara, T., Osumi, N. and Noda, M. (2000). Identification of RALDH-3, a novel retinaldehyde dehydrogenase, expressed in the ventral region of the retina. Mech. Dev. 98, 3750.

Swindell, E. C., Thaller, C., Sockanathan, S., Petkovich, M., Jessell, T. M. and Eichele, G. (1999). Complementary domains of retinoic acid production and degradation in the early chick embryo. Dev. Biol. 216, 282-296.

Szuts, E. Z. and Harosi, F. I. (1991). Solubility of retinoids in water. Arch Biochem. Biophys. 287, 297-304.

Tahayato, A., Dollé, P. and Petkovich, M. (2003). Cyp26C1 encodes a novel retinoic acid-metabolizing enzyme expressed in the hindbrain, inner ear, first branchial arch and tooth buds during murine development. Gene Expr. Patterns 3. 449-454.

Tang, X. H. and Gudas, L. J. (2011). Retinoids, retinoic acid receptors, and cancer. Annu. Rev. Pathol. 6, 345-364.

Thaller, C. and Eichele, G. (1987). Identification and spatial distribution of retinoids in the developing chick limb bud. Nature 327, 625-628.

Tickle, C., Alberts, B., Wolpert, L. and Lee, J. (1982). Local application of retinoic acid to the limb bond mimics the action of the polarizing region. Nature 296, 564-566.
Uehara, M., Yashiro, K., Mamiya, S., Nishino, J., Chambon, P., Dollé, P. and Sakai, Y. (2007). CYP26A1 and CYP26C1 cooperatively regulate anteriorposterior patterning of the developing brain and the production of migratory cranial neural crest cells in the mouse. Dev. Biol. 302, 399-411.

Uehara, M., Yashiro, K., Takaoka, K., Yamamoto, M. and Hamada, H. (2009). Removal of maternal retinoic acid by embryonic CYP26 is required for correct Nodal expression during early embryonic patterning. Genes Dev. 23, 16891698

Vermot, J. and Pourquie, O. (2005). Retinoic acid coordinates somitogenesis and left-right patterning in vertebrate embryos. Nature 435, 215-220.

Vermot, J., Niederreither, K., Garnier, J. M., Chambon, P. and Dollé, P. (2003). Decreased embryonic retinoic acid synthesis results in a DiGeorge syndrome phenotype in newborn mice. Proc. Natl. Acad. Sci. USA 100, 1763-1768.

Vermot, J., Gallego Llamas, J., Fraulob, V., Niederreither, K., Chambon, P. and Dollé, P. (2005). Retinoic acid controls the bilateral symmetry of somite formation in the mouse embryo. Science 308, 563-566.

Vilhais-Neto, G. C., Maruhashi, M., Smith, K. T., Vasseur-Cognet, M., Peterson, A. S., Workman, J. L. and Pourquie, O. (2010). Rere controls retinoic acid signalling and somite bilateral symmetry. Nature 463, 953-957.

Vitobello, A., Ferretti, E., Lampe, X., Vilain, N., Ducret, S., Ori, M., Spetz, J. F., Selleri, L. and Rijli, F. M. (2011). Hox and Pbx factors control retinoic acid synthesis during hindbrain segmentation. Dev. Cell 20, 469-482.

Wang, Z., Dollé, P., Cardoso, W. V. and Niederreither, K. (2006). Retinoic acid regulates morphogenesis and patterning of posterior foregut derivatives. Dev. Biol. 297, 433-445.

Ward, S. J., Chambon, P., Ong, D. E. and Bavik, C. (1997). A retinol-binding protein receptor-mediated mechanism for uptake of vitamin A to postimplantation rat embryos. Biol. Reprod. 57, 751-755.

Wendling, O., Chambon, P. and Mark, M. (1999). Retinoid X receptors are essential for early mouse development and placentogenesis. Proc. Natl. Acad. Sci. USA 96, 547-551.

Wendling, O., Dennefeld, C., Chambon, P. and Mark, M. (2000). Retinoid signaling is essential for patterning the endoderm of the third and fourth pharyngeal arches. Development 127, 1553-1562.

Wendling, O., Ghyselinck, N. B., Chambon, P. and Mark, M. (2001). Roles of retinoic acid receptors in early embryonic morphogenesis and hindbrain patterning. Development 128, 2031-2038.

White, J. C., Highland, M., Kaiser, M. and Clagett-Dame, M. (2000). Vitamin A deficiency results in the dose-dependent acquisition of anterior character and shortening of the caudal hindbrain of the rat embryo. Dev. Biol. 220, 263-284.

White, R. J. and Schilling, T. F. (2008). How degrading: Cyp26s in hindbrain development. Dev. Dyn. 237, 2775-2790.

White, R. J., Nie, Q., Lander, A. D. and Schilling, T. F. (2007). Complex regulation of cyp26a1 creates a robust retinoic acid gradient in the zebrafish embryo. PLoS Biol. 5, e304

Wilson, J. G., Roth, C. B. and Warkany, J. (1953). An analysis of the syndrome of malformations induced by maternal vitamin A deficiency. Effects of restoration of vitamin A at various times during gestation. Am. J. Anat. 92, 189217

Wilson, L., Gale, E., Chambers, D. and Maden, M. (2004). Retinoic acid and the control of dorsoventral patterning in the avian spinal cord. Dev. Biol. 269, 433446

Wilson, V., Olivera-Martinez, I. and Storey, K. G. (2009). Stem cells, signals and vertebrate body axis extension. Development 136, 1591-1604.

Wolpert, L. (2011). Positional information and patterning revisited. J. Theor. Biol. 269, 359-365

Yashiro, K., Zhao, X., Uehara, M., Yamashita, K., Nishijima, M., Nishino, J., Saijoh, Y., Sakai, Y. and Hamada, H. (2004). Regulation of retinoic acid distribution is required for proximodistal patterning and outgrowth of the developing mouse limb. Dev. Cell 6, 411-422

Zhang, J., Smith, D., Yamamoto, M., Ma, L. and McCaffery, P. (2003). The meninges is a source of retinoic acid for the late-developing hindbrain. J. Neurosci. 23, 7610-7620.

Zhao, X., Sirbu, I. O., Mic, F. A., Molotkova, N., Molotkov, A., Kumar, S. and Duester, G. (2009). Retinoic acid promotes limb induction through effects on body axis extension but is unnecessary for limb patterning. Curr. Biol. 19, 10501057 